\title{
DIAGNÓSTICO DA SECAGEM CONVENCIONAL DE MADEIRAS NO ESTADO DE SÃO PAULO
}

\author{
MARCOS ANDRÉ DUCATTI \\ Engenheiro Florestal
}

Orientador: Prof. Dr. IVALDO PONTES JANKOWSKY

\begin{abstract}
Dissertação apresentada à Escola Superior de Agricultura "Luiz de Queiroz", Universidade de São Paulo, para obtenção do título de Mestre em Ciências, Área de Concentração: Ciências e Tecnologia de Madeiras.
\end{abstract}

PIRACICABA

Estado de São Paulo - Brasil

Fevereiro - 2000 


\section{ERRATA}

\begin{tabular}{|c|c|c|}
\hline $\begin{array}{l}\text { Pág/Parágrafo/ } \\
\text { Linha }\end{array}$ & Onde se lê... & Leia-se ... \\
\hline $6 / 2 / 3$ & ...pontoações aureoladas.. & ...pontoações areoladas. \\
\hline $18 / 5 / 1$ & c) Secagem convencional & b) Secagem convencional \\
\hline $20 / 4 / 1$ & 3.4 A evolução da secagem da ....... & 3.5 A evolução da secagem da \\
\hline $24 / 6 / 2$ & ...segmento, que engloba ... & $\begin{array}{l}\text {...segmento (setor madeira/mobiliário), que } \\
\text { engloba ... }\end{array}$ \\
\hline $26 / 2 / 1$ & No Brasil (Nahuz, 1988), & Segundo Nahuz (1988), ... \\
\hline $34 / 1 / 2$ & ...questionário básico (Anexo A), ... & ...questionário simplificado (Anexo A), \\
\hline $34 / 4 / 2$ & ...questionário completo (Anexo B), & ...questionário detalhado (Anexo B), \\
\hline $36 / 2 / 1$ & $\begin{array}{l}\text { Em laboratório foram feitos os } \\
\text { ensaios.... }\end{array}$ & $\begin{array}{l}\text { Em laboratório, assim que se terminava a } \\
\text { coleta do material para análise em cada } \\
\text { indústria, eram feitos os ensaios....... }\end{array}$ \\
\hline $41 / 1 / 3$ & $\begin{array}{l}\text {...convencional não é comparável com } \\
\text { a indústria norte-americana. É ... }\end{array}$ & $\begin{array}{l}\text {...convencional é muito baixa quando } \\
\text { comparada com alguns estados Norte- } \\
\text { americanos (Tabela 1). } \dot{E} \ldots\end{array}$ \\
\hline $41 / 3 / 6$ & ...pequenos volumes de madeira. & $\begin{array}{l}\text {...pequenos volumes de madeira, ou seja, } \\
\text { capacidade abaixo de } 20 \mathrm{~m}^{3} \text {. }\end{array}$ \\
\hline $\begin{array}{l}\text { 43/Tabela.3/ } \\
\text { última }\end{array}$ & 43 & $43(*)$ \\
\hline $44 / 1 / 1$ & $\begin{array}{l}\text {..6, } 7 \text { e } 8 \text { mostram uma melhor } \\
\text { ilustração das formas .... }\end{array}$ & $\ldots 6,7$ e 8 ilustram as formas $\ldots .$. \\
\hline $54 / 2 / 3$ & ...informações obtidas demostram a & ...informações obtidas demonstram a .... \\
\hline $54 / 3 / 3$ & ...uma mesma faixa. Entretanto, os & $\begin{array}{l}\text {...uma mesma faixa, e ainda, praticam a } \\
\text { pré-secagem o que torna a produção mais } \\
\text { econômica, aumenta a produtividade e } \\
\text { permite um melhor aproveitamento do } \\
\text { secador. Entretanto, os... }\end{array}$ \\
\hline $56 / 3 / 3$ & ...observado na Tabela 13. & $\begin{array}{l}\text {...observado na Tabela } 13 . \text { É interessante } \\
\text { comentar que uma porcentagem da } \\
\text { incidência de defeitos pode estar } \\
\text { relacionado com as características da } \\
\text { espécie. }\end{array}$ \\
\hline $58 / 1 / 4$ & $\begin{array}{l}\text {...vertical da pilha (distância constante } \\
\text { entre separadores). }\end{array}$ & $\begin{array}{l}\text {... vertical e horizontal da pilha (distância } \\
\text { constante entre os separadores). }\end{array}$ \\
\hline $58 / 2 / 4$ & ... falta de condicionamento no final... & $\begin{array}{l}\text {... falta ou tempo inadequado de } \\
\text { condicionamento no final .... }\end{array}$ \\
\hline $60 / 1 / 2$ & $\begin{array}{l}\text {...secador longo e estreito, enquanto } \\
\text { que uma característica construtiva do } \\
\text { secador de carga por empilhadeira (B) } \\
\text { e ser largo e profundo. }\end{array}$ & $\begin{array}{l}\text {...secador longo e estreito (retangular), } \\
\text { enquanto que uma característica } \\
\text { construtiva do secador de carga por } \\
\text { empilhadeira (B) e ser largo e profundo } \\
\text { (quadrado). }\end{array}$ \\
\hline
\end{tabular}


Dados Internacionais de Catalogação na Publicação (CIP) DIVISĀO DE BIBLIOTECA E DOCUMENTAÇĀO - Campus "Luiz de Queiroz"/USP

\section{Ducatti, Marcos André}

Diagnóstico da secagem convencional de madeiras no estado de São Paulo / Marcos André Ducatti. - - Piracicaba, 2000.

$$
83 \text { p. : il. }
$$

Dissertaçāo (mestrado) -. Escola Superior de Agricultura Luiz de Queiroz, 2000. Bibliografia.

1. Controle de qualidade 2. Indústria madeireira 3. Secador 4. Secagem da madeira I. Titulo

$\operatorname{CDD} 674.38$ 
Aos meus pais (Octávio-Tereza Ducatti) e à memória de meus avós (Francisco-Santa Vendrame e Alberto-Olga Ducatti) 


\section{AGRADECIMENTOS}

- aos meus pais, Octávio-Tereza, pelo apoio e incentivo ao longo do trabalho;

- ao amigo Prof. Dr. Ivaldo P. Jankowsky e sua família (Neide, Luciana e Maíra), não somente pela sua orientação acadêmica mas também pelo apoio nas oportunidades profissionais;

- as pessoas mais que especiais: Fabiane Ducatti, Francisco-Doris Ducatti, Sandra Victor e Familia, Pedro Victor e Vitor Ducatti;

- aos professores da Escola Superior de Agricultura "Luiz de Queiroz", pelos conhecimentos transmitidos;

- ao CNPq, pela concessão da bolsa de mestrado;

- aos amigos do curso de PG em Ciência e Tecnologia de Madeiras;

- aos professores e técnicos do IPT;

- a equipe do Laboratório de Secagem de Madeiras da ESALQ/USP ;

- a Marialice Poggiani e sua equipe Paulo e Taís, pela boa vontade e paciência

- as indústrias, Indusparquet -Ind. Com. Madeiras Ltda (José Antônio Baggio e Kiko Uliana), Indústria Madeireria Uliana Ltda (Sr. Ídrico Uliana, Antonio Carlos Uliana, José Arnaldo Uliana e Moacir Uliana), Esul - Esquadrias Uliana Ltda (Sr. Alcidez Uliana, Mauro Claúdio e Sérgio Uliana), Caribea - Ind. Madeireira Ltda (José Valdir Mondini) e Ulimax - Esquadrias de Madeiras Ltda (Roberto Uliana e Márcio Uliana);

- aos amigos José Antonio Baggio e Luis Francisco Uliana pelo grande apoio à minha vida profissional;

- aos amigos (engenherandos) de toda hora: Ariel Andrade, Inês Galina e Gianpaola Ciniglio - e suas familias - pelas contribuições, sugestões e discussões;

- aos amigos Daniel Pagano, Jefferson Polizel, Luciane Zaia, Marilia Cantarelli, James Marafon, Marcelo Lavora, Ana Helena Felício, Deisiane Lúcio, Juliana Bouchardet, e a todos os outros que de alguma maneira contribuíram para realização deste trabalho, e que não foram citados, mas que não são menos importantes. 


\section{SUMÁRIO}

LISTA DE FIGURAS ................................................................. vii

LISTA DE TABELAS .................................................................... viii

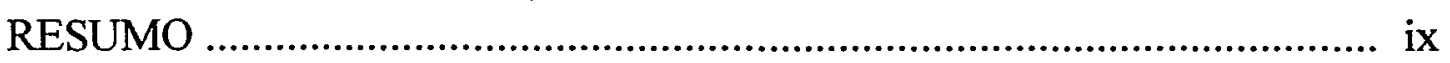

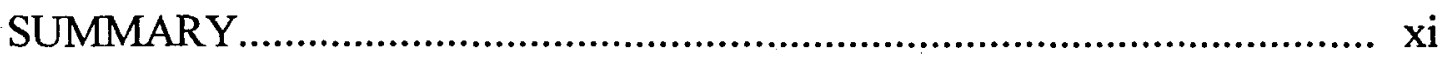

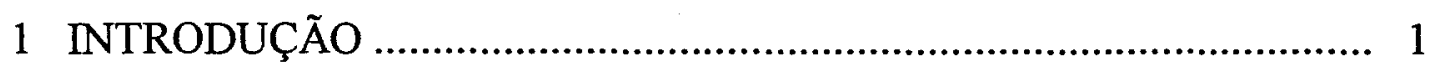

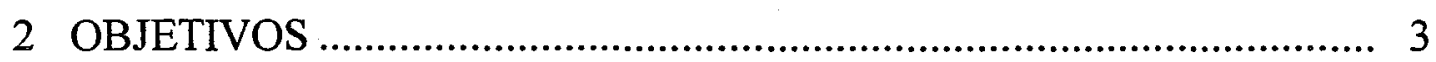

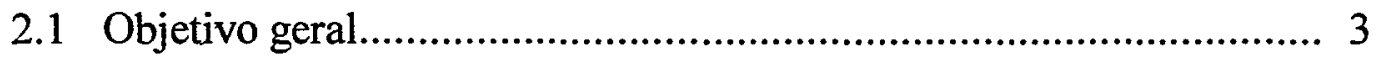

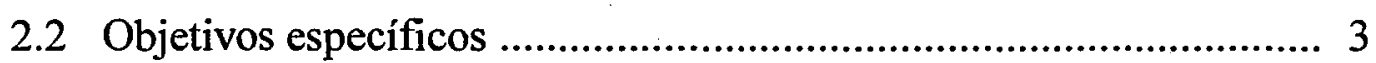

3 REVISÃO BIBLIOGRÁFICA.................................................... 4

3.1 Secagem da madeira.............................................................. 4

3.2 Princípios fisicos da secagem................................................. 7

3.3 Defeitos de secagem............................................................. 11

3.4 Processos de secagem mais utilizados......................................... 17

3.5 A evolução da secagem da madeira nas indústrias de

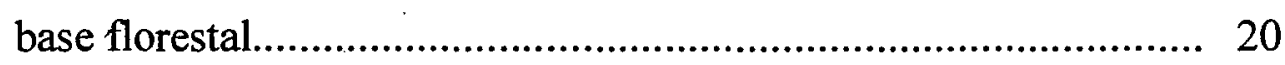

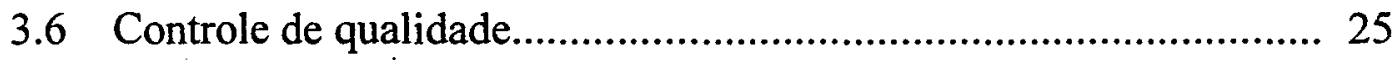

3.7 Pesquisa de mercado............................................................... 29

4 MATERIAL E MÉTODOS............................................................ 32

4.1 Quantificação e qualificação das indústrias.................................... 33

4.2 Avaliação do questionário........................................................... 33

4.3 Consulta às indústrias............................................................. 33

4.4 Levantamento em campo............................................................ 34

4.5 Amostragem e testes em laboratório............................................ 35 


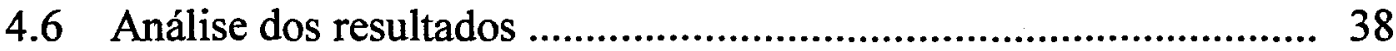

5 RESULTADOS E DISCUSSÃO........................................................ 39

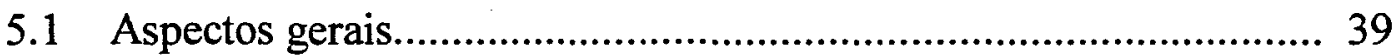

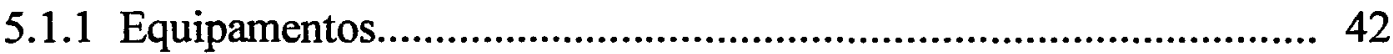

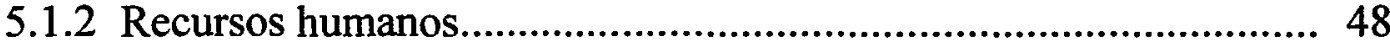

5.1.3 Espécies utilizadas................................................................. 49

5.2 Características e práticas operacionais (questionário detalhado).... 50

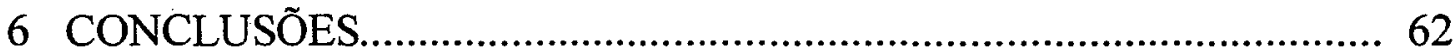

Anexo A - QUESTIONÁRIO SIMPLIFICADO ..................................... 64

Anexo B - QUESTIONÁRIO DETALHADO .........................................6 66

REFERÊNCIAS BIBLIOGRÁFICAS ................................................. 75

Apêndice 1 - ESPÉCIES UTILIZADAS ................................................ 82 


\section{LISTA DE FIGURAS}

Figura 1 Tipos de empenamentos da madeira (Ponce \& Watai, 1985) ......................................................... 14

Figura 2 Esquema resumido da metodologia ..................................... 32

Figura 3 Retirada dos corpos de prova para os testes de qualidade em laboratório (Rasmussen, 1961 e Ciniglio, 1998) ....................... 37

Figura 4 Classificação das tensões (adaptada de Pratt, 1974 e Ciniglio, 1998) .................................................................. 38

Figura 5 Localização dos secadores convencionais no estado de São Paulo. 40

Figura 6 Secador construído em alvenaria e carregado por empilhadeira

Figura 7 Secador carregado por vagonete e construído totalmente em alumínio

Figura 8 Secador construído em alvenaria (parede) e alumínio (outros componentes), carregado por vagonete.

Figura 9 Empilhamento realizado de forma incorreta............................... 57

Figura 10 Forma correta de empilhamento ............................................ 57 


\section{LISTA DE TABELAS}

Tabela 1 Comparação da capacidade de secagem convencional do estado de São Paulo com estados Norte-americanos

Tabela 2 Características dos secadores em operação no estado de São Paulo

Tabela 3 Distribuição dos secadores convencionais no estado de São Paulo

Tabela 4 Distribuição dos secadores convencionais no estado de São Paulo de acordo com a capacidade e forma de carregamento

Tabela 5 Secadores convencionais construídos antes e após 1990, no estado de São Paulo

Tabela 6 Qualificação dos recursos humanos envolvidos na operação de secagem

Tabela 7 Distribuição das espécies secas pelo método convencional 49

Tabela 8 Informações gerais das indústrias amostradas (questionário detalhado)

Tabela 9 Características dos secadores 52

Tabela 10 Características dos sistemas de controle da secagem 53

Tabela 11 Qualificação dos operadores de secador 54

Tabela 12 Uniformidade no preparo da carga 55

Tabela 13 Quantificação dos defeitos de secagem ..................................... 56

Tabela 14 Incidência das tensões de secagem (em \% do total de amostras) .... 58

Tabela 15 Distribuição de umidade 59 


\section{DIAGNÓSTICO DA SECAGEM CONVENCIONAL DE MADEIRAS NO ESTADO DE SÃO PAULO}

Autor: MARCOS ANDRÉ DUCATTI

Orientador: Prof. IVALDO PONTES JANKOWSKY

\section{RESUMO}

Nos diferentes processos de transformação da madeira maciça em produtos industrializados, a secagem é a fase intermediária que mais contribui para agregar valor ao produto final. Contudo, tanto a falta de informações técnicas como o desinteresse por parte das indústrias tem contribuído para desqualificar a indústria de base madeireira; problema já registrado em levantamentos efetuados em 1964 e 1974.

A partir da década de 80 intensificou-se a difusão da tecnologia de secagem, através da formação de recursos humanos, realização de cursos técnicos, seminários, publicações e congressos; complementada pela abertura comercial ocorrida na década de 90 , a qual facilitou a aquisição de equipamentos modernos com tecnologia mais atual. 
Torna-se importante, no momento atual, avaliar como a indústria madeireira está utilizando a tecnologia e os conhecimentos disponíveis.

Assim, o presente trabalho teve como objetivo realizar um diagnóstico das condições operacionais da secagem convencional de madeiras, no estado de São Paulo; de forma a avaliar o atual estágio tecnológico, verificar quais aspectos que ainda prejudicam a qualidade do produto (madeira seca) e, quando possivel, sugerir iniciativas no sentido de contribuir para o desenvolvimento industrial.

As informações obtidas permitiram localizar 43 indústrias usando secadores convencionais. $O$ levantamento junto a essas indústrias permitiu concluir que a qualificação da força de trabalho ainda deve ser considerada como prioridade, e que a principal prática operacional a ser aprimorada é a preparação da madeira (empilhamento) para a secagem.

Nas indústrias que buscam agregar valor ao produto final existe o reconhecimento sobre a importância da secagem no processo produtivo, mas o padrão de qualidade da madeira seca ainda está abaixo das referências de literatura. Para atingir e manter um padrão de qualidade superior sugere-se a execução de procedimentos diretamente voltados ao controle de qualidade, principalmente quanto a quantificação de defeitos, da distribuição de umidade e das tensões residuais. 


\title{
DIAGNOSTIC OF CONVENTIONAL KILN DRYING PROCESS IN THE STATE OF SÃO PAULO
}

\author{
Author: MARCOS ANDRÉ DUCATTI \\ Adviser: Prof. IVALDO PONTES JANKOWSKY
}

\section{SUMMARY}

On the different processes involving manufacturing of raw wood into a final, ready to use product, the kiln drying process is by far the most important step, responsible in great share for adding value to the product. Unfortunately, lack of technical information and interest from the industry had contributed negative on the base wood working companies; problem of which had already been appointed on researches made on 1964 and 1974.

In the 80 's the attention to the wood drying technology had been intensified through a formation of human resources, availability of technical courses, seminars, publications and conventions covering the issue; helped as well in the 90's for the opening of the Brazilian economy, making easier for the acquisitions of up to date technological equipment. 
Now days, it's important to analyze how our wood industry are using the knowledge and technology available.

So, the objective of this research was to analyze the conventional wood drying conditions, in the State of São Paulo; in a way to evaluate today's technological stage, verify which aspects are still damaging the quality of the final product (dried wood) and, as often as possible, to came up with suggestions that can contribute to a better industrial development.

The information gathered added up to a 43 industries that are using conventional dryers. The results based on their information point to a conclusion that the labor force has to be considered as priority, and that the preparation of the green lumber (stacking), prior to its drying process, is to date the stage which could use some help and technical advises.

It's clear the recognition for the drying technology on a production line, for the industries that are trying to add value to its final products, but the dried wood available today still bellow the average quality expected. In order to reach a higher level of quality and keep it that way, it is suggested that the processes direct related to quality control should be precisely executed, especially when raising defect standards, distribution of moisture content and residual drying stress. 


\section{INTRODUÇÃO}

A secagem é considerada uma das fases mais importantes em uma indústria madeireira. A introdução de métodos artificiais, quando dentro de técnicas corretas, tem beneficiado o setor com uma maior flexibilidade para atender o mercado consumidor, obtenção de produtos de maior valor agregado, proteção eficaz da madeira e obtenção de teores de umidade desejados.

Embora a secagem seja um processo intermediário, é muito importante para garantir a qualidade do produto final. Porém, poucas indústrias de transformação da madeira no Brasil dão o valor necessário a essa fase. Talvez esse desinteresse ocorra, principalmente, devido a falta de informações e a estudos realizados sobre as condições da secagem. Esse fato vem sendo observado desde os primeiros levantamentos realizados no país.

Por volta de 1960 , verificou-se que os principais problemas do setor estavam relacionados a essa fase, e que nessa época o produto brasileiro estava desmoralizado na Europa Ocidental (CODEPAR, 1964).

Posteriormente TOMASELLI (1974), realizou um trabalho visando obter informações das condições de secagem artificial de madeiras serradas no Paraná e Santa Catarina, chegando a conclusão que a situação continuava quase que a mesma. Esse trabalho sugeria tomar determinadas atitudes a curto espaço de tempo, através de orgãos governamentais, associações de classe, e da própria indústria, afim de melhorar a situação técnica do setor. 
Um outro aspecto negativo observado estava relacionado com os secadores em si, que eram construídos copiando esquemas de equipamentos estrangeiros e tidos como ultrapassados.

A partir de 1990, com a abertura do mercado nacional e com a diminuição das alíquotas de importação, muitas indústrias adquiriram equipamentos de tecnologia mais atual. Contudo, nem sempre o investimento é feito de forma criterioso, analisando-se aspectos como o nível tecnológico, capacidade real, custos, dentre outros .

A possibilidade das indústrias madeireiras trabalharem com equipamentos mais modernos pode complementar o desenvolvimento tecnológico gerado pela difusão da tecnologia de secagem; que vem ocorrendo a partir da década de 80, através de seminários, cursos, publicações de artigos técnicos e congressos.

Entretanto, não existem informações que permitam avaliar se a disponibịlidade de informações e de tecnologia está sendo utilizada pela indústria. Assim, o presente estudo, que constou de um levantamento das condições da secagem convencional de madeiras, pretendeu verificar qual o nivel tecnológico da indústria madeireira no estado de São Paulo. 


\section{OBJETIVOS}

\subsection{Objetivo geral}

Realizar um diagnóstico das condições operacionais da secagem convencional de madeiras serradas no estado de São Paulo.

\subsection{Objetivos específicos}

- obter informações que permitam avaliar o estágio tecnológico atual;

- verificar quais os principais aspectos que ainda prejudicam a qualidade do produto (madeira seca);

- sugerir iniciativas no sentido de contribuir com o desenvolvimento tecnológico da indústria e aprimorar o padrão de qualidade dos produtos. 


\section{REVISÃO BIBLIOGRÁFICA}

\subsection{Secagem de madeiras}

O tronco da árvore viva está saturado de uma solução diluída de sais minerais denominada seiva. Esta solução, que permanece na madeira após o corte e desdobro desse tronco, é considerada, para fins de secagem, como sendo apenas água (Henriquez, 1986).

Após o seu desdobro, a madeira tende a perder umidade com maior ou menor rapidez dependendo da espécie, espessura, das condições de armazenamento e das condições ambientais até atingir o equilíbrio higroscópico com o ar que a envolve (Galvão \& Jankowsky, 1985).

A perda de umidade pela madeira causa sua retração volumétrica, principal razão pela qual recomenda-se a secagem do material madeira antes da sua transformação em bens e produtos.

Lamb (1994) considera que a madeira está adequadamente seca, quando apresentar as seguintes condições:

- livre de defeitos visíveis ( rachaduras, empenamentos, colapso e manchas);

- teor de umidade compatível com o uso pretendido;

- mínimo de variação no teor de umidade, tanto dentro como entre as peças;

- livre das tensões de secagem. 
Favorecer a perda de umidade, seja de forma natural ou artificial, até que a madeira esteja adequadamente seca constitui o processo de secagem.

$\mathrm{Da}$ água a ser retirada da madeira durante a secagem, devem ser destacadas as duas formas mais importantes: água livre ou de capilaridade e água higroscópica.

a) Água livre ou de capilaridade

Encontrada nos lúmes dos vasos, traqueídes, parênquima radial e axíal, canais epiteliais e intercelulares e fibras. Este tipo de água movimenta-se na madeira através das aberturas naturais das células, por fenômenos de capilaridade, deslocando-se do local mais úmido para o menos úmido. De modo geral, é o primeiro tipo de água a ser removida durante o processo de secagem (Siau, 1971 e Skaar, 1988).

Segundo Kollmann \& Côté (1968), a água livre na madeira está retida por forças capilares e movimenta-se pelas aberturas naturais do material, até o ponto de saturação das fibras (PSF) ser atingido. Conforme demostram vários estudos, o PSF varia numa faixa de umidade de 25 a $35 \%$, em função da espécie.

A movimentação da água livre é realizada através das aberturas naturais, e o fator limitante à sua retirada é a permeabilidade, caracterizada pela maior ou menor facilidade com que a água escoa através da madeira em uma determinada direção (Brandão, 1989).

Siau (1971), Skaar (1988) e Galvão (1976), demonstram que a permeabilidade da madeira é maior no sentido longitudinal ou paralelo às fibras, 
em comparação com o sentido transversal, sendo maior no sentido radial do que no tangencial.

No caso das coniferas a permeabilidade longitudinal está diretamente relacionada com o número, tamanho, distribuição e condição das pontoações aureoladas, já que é através destas estruturas que se dá o fluxo. Siau (1971), encontrou que as pontoações das coniferas são responsáveis por $80 \%$ da resistência à passagem de um fluido na madeira.

O mesmo autor cita que, para folhosas, o fluxo de água no sentido longitudinal é mais acentuado do que o fluxo transversal devido o maior diâmetro dos vasos comparados ao tamanho das pontoações das fibras e raios.

b) Água higroscópica

Água aderida as paredes celulares, sendo removida através de fenômeno de difusão ou fenômenos análogos. Altera as propriedades da madeira $\mathrm{e}$ é difícil de ser removida durante a secagem. A água higroscópica movimenta-se através da parede celular por causa de um gradiente de umidade (Ponce \& Watai, 1985).

O movimento da água higroscópica pode ser considerado como um processo de difusão. Durante a realização desse processo, as moléculas de água se deslocam de um local de sorção para outro (Brandão, 1989).

A difusão da água higroscópica ocorre em combinação com a difusão do vapor d'água. Durante o seu percurso para a superfície da madeira, a molécula de água atravessa o lúme da célula (já livre da água capilar), no estado de vapor, até atingir novamente a parede celular, passando então a ocorrer o mecanismo de difusão da água higroscópica. Esta combinação de mecanismos será repetida até que a molécula de água atinja a superficie da madeira. 
Na madeira, o fluxo de água higroscópica varia conforme sua direção, recebendo valores diferentes no coeficiente de difusão. Para a água higroscópica, a velocidade de difusão no sentido longitudinal é de 2 a 3 vezes maior que no sentido transversal (Henriquez, 1986).

A perda de água higroscópica acarreta a diminuição de volume da madeira. Essa retração irá ocorrer até que a madeira atinja a condição de equilíbrio higroscópico com o meio, denominada de umidade de equilíbrio (UE), a qual pode ser definida como o teor de umidade que a madeira atingirá quando colocada ao ar, sob uma condição constante de temperatura e umidade relativa.

De acordo com Galvão \& Jankowsky (1985), através da secagem artificial, pode-se diminuir a higroscopicidade da madeira e a sua posterior retração, além de se chegar a umidade desejada mais rapidamente.

\subsection{Princípios físicos da secagem}

A secagem de madeiras, basicamente se desenvolve em duas fases simultâneas. Na primeira, ocorre a remoção da água superficial, e na segunda, a movimentação da água do interior das peças para superfície (Galvão \& Jankowsky, 1985).

Segundo Hart (1965), do ponto de vista físico, a secagem de madeiras pode ser definida como um balanço dinâmico entre a transferência de calor da corrente de ar para a madeira, a evaporação superficial na madeira, difusão de umidade através da madeira e o fluxo de massa da água livre. 
O calor é transferido do meio de secagem (ar) para a superfície da madeira por convecção. Após a superfície ser aquecida, este calor é transferido para o interior por condução. No início da secagem, quando a madeira está muito úmida, a transferência de calor à superfície é o fator mais importante. À medida que a madeira diminui o seu teor de umidade, a transferência de calor da superfície para o interior passa a ser o fator limitante. É por esta razão que altas velocidades de ar são mais importantes na primeira fase de secagem do que no final. Equipamentos modernos de secagem permitem variar a velocidade do ar durante o processo (STCP, 1990).

A transferência de calor e a evaporação são controladas pelas condições externas e o movimento de umidade do interior até a superficie da madeira é condicionado, principalmente, por propriedades da madeira como a permeabilidade e a massa específica (Jankowsky, 1989).

Dessa forma, é pertinente considerar que o processo de secagem pode ser influenciado por fatores intrínsecos (relacionados a madeira) e extrínsecos (relacionados ao meio de secagem).

a) Fatores intrínsecos

Diversos autores, dentre eles Burger \& Richter, (1991) e Perelygin, (1965), discutem a influência das características da madeira na movimentação de fluidos e no tempo requerido para a secagem. Os principais aspectos são:

teor de umidade: para um mesmo tipo (espécie) de madeira, quanto maior o teor de umidade inicial (maior massa de água a ser removida), maior será o tempo de secagem; 
massa específica: o aumento na massa específica implica em maior massa de água higroscópica e menor de água capilar. Uma vez que a água higroscópica movimenta-se por difusão através das paredes das fibras e requer um adicional de energia para romper as ligações entre moléculas, maior massa específica também significa maior dificuldade na remoção da água higroscópica. A movimentação da água capilar dependerá principalmente da permeabilidade;

permeabilidade: medida de facilidade de escoamento de um fluido através de um material poroso. Depende essencialmente da estrutura anatômica da madeira, principalmente do diâmetro e desobstrução das pontoações. Quanto mais permeável a madeira, mais fácil será a retirada da água líquida;

cerne e ałburno :o alburno é mais permeável do que o cerne, assim, a movimentação de água no cerne é mais lenta;

orientação dos anéis de crescimento: nas tábuas de corte tangencial os raios estão posicịonados no sentido da espessura, enquanto que em uma tábua radial estarão posicionados no sentido da largura. Como os raios favorecem o escoamento da água líquida, as tábuas tangenciais tendem a secar mais rapidamente;

espessura das tábuas: a velocidade de secagem é inversamente proporcional à espessura das tábuas, pois o aumento na espessura implica também no aumento da proporção entre volume (maior massa de água) e área superficial 
b) Fatores extrinsecos

Nos métodos mais usuais para secagem da madeira é utilizado o ar como meio de transferência; e as características do ar que podem afetar o processo são a temperatura, a umidade relativa e a velocidade de deslocamento.

temperatura : normalmente, quanto maior a temperatura, menor é o tempo de secagem, pois o aumento de temperatura aumenta a quantidade de energia necessária para evaporação da água na superfície da madeira. É evidente que existem limites de temperatura que devem ser observados para que não ocorra degradação do material;

velocidade do ar : fator altamente importante, agindo em dois aspectos : transferência de calor (energia) à superfície da madeira e transferência de massa da superfície (vapor d'água) para o meio. Um aumento na velocidade do ar implica em um aumento na velocidade de secagem. Deve-se observar que é importante um balanceamento entre velocidade do ar e temperatura de secagem, sendo que o aumento na temperatura deve normalmente ser acompanhado de um aumento na velocidade do ar, principalmente no início de secagem e para madeiras permeáveis (Tomaselli, 1979).

umidade relativa do ar: a umidade relativa do ar está relacionada com a capacidade do ar em receber maior ou menor quantidade de vapor d'água e com a remoção da água da superfície da madeira. Portanto, quanto menor a 
umidade relativa do ar, maior a quantidade de água que o ar pode conter (Galvão \& Jankowsky, 1985).

Além das características do ar, outro fator (extrínseco) a ser destacado é a preparação da madeira para a secagem. O correto empilhamento é de extrema importância na homogeneidade da secagem e, principalmente, na qualidade das peças ao final do processo.

Para que o período de secagem e os defeitos diminuam é recomendado que a carga seja preparada com madeiras de mesma espécie, espessura e com umidade inicial bem próximas. Outro fator importante é a escolha dos separadores que devem ser de madeiras duras, sem defeitos, com grã reta, secos em estufa e dimensões uniformes. O posicionamento, espaçamento e o alinhamento dos separadores, também são importantes durante o processo de secagem, principalmente como medida preventiva para diminuir a incidência de empenamentos.

Em consequência, a falta de controle desses fatores poderá causar sérios problemas a qualidade do produto madeira seca, ou seja, surgirão defeitos, acarretando perda de material e diminuição da produtividade.

\subsection{Defeitos de secagem}

Martins (1988) comenta que os defeitos decorrentes da secagem causam significativos prejuízos para quem seca madeira e desestimula a utilização de determinadas espécies; contribuindo para a exploração seletiva e para o reduzido número de espécies atualmente comercializadas. 
Segundo Brandão (1989), defeito de secagem é toda e qualquer alteração que venha a ocorrer na estrutura da madeira que dificulte seu reprocessamento, em uma fase posterior.

Os principais defeitos de secagem são conhecidos como colapso, rachaduras, empenamentos e endurecimento superficial.

Colapso é definido como sendo um achatamento ou deformação das células durante a secagem, evidenciando uma contração excessiva e/ou desigual. Esse tipo de defeito ocorre na madeira acima do ponto de saturação das fibras (Brandão, 1989).

Para Galvão \& Jankowsky (1985), o colapso caracteriza-se por ondulações nas superficies da peça de madeira, que podem apresentar-se bastante distorcidas, e é ocasionado, basicamente, por forças geradas durante a movimentação da água capilar, as quais deformam as células. Segundo Skaar (1972), a principal causa do colapso é a tensão capilar, que se manifesta nas fases iniciais de secagem, quando o teor de umidade da madeira está acima do PSF. De uma forma geral, os fatores que influem no colapso são: pequeno diâmetro dos capilares, altas temperaturas no início da secagem, baixa densidade da madeira e alta tensão superficial do líquido que é removido da madeira

De acordo com STCP (1990), a intensidade de colapso aumenta com a temperatura, portanto, para reduzir sua intensidade deve-se reduzir a temperatura de secagem, pelo menos até a madeira atingir o PSF. A temperatura máxima neste início não deve ultrapassar $50^{\circ} \mathrm{C}$.

Com exceção do colapso, que está relacionado com o fluxo capilar e a permeabilidade da madeira, os demais defeitos de secagem estão de alguma forma ligados às diferentes retrações verificadas na madeira (Henriquez, 1986). 
Empenamentos, segundo Galvão \& Jankowsky (1985), são quaisquer distorções da peça de madeira em relação aos planos originais da sua superficie, como podem ser observados na Figura 1, e são decorrentes das retrações diferenciadas que podem ocorrer na peça submetida a secagem, causadas tanto pela anisotropia da madeira como pelas diferenças entre cerne e alburno, lenhos inicial e tardio ou madeira juvenil e adulta.

Para se diminuir a incidência de empenamentos, cuidados devem ser tomados logo após a operação de desdobro. $\mathrm{Na}$ preparação das pilhas para secagem, recomenda-se a formação de pilhas planas, utilizando-se, para isto, separadores com idênticas dimensões. Este defeito poderá ocorrer durante a secagem, principalmente quando não se tem um controle adequado da velocidade de remoção de água nos estágios iniciais do processo. Assim sendo, deve-se evitar, ao máximo, umidade relativas muito baixas no início da secagem de madeiras verdes (Oliveira, 1981).

Outro defeito muito comum são as rachaduras. As rachaduras são aberturas estreitas e longas que aparecem tanto na superficie como nos topos, e, juntamente com o endurecimento superficial ou encruamento, ocorrem devido a secagem muito rápida da superficie. As rachaduras podem também ser causadas pelas diferenças nas contrações radiais e tangenciais, resultando em tensões de magnitude suficiente para causar a ruptura da madeira ao longo dos planos mais fracos, geralmente nas junções do tecido longitudinal (fibras, vasos, traqueídes, etc). 


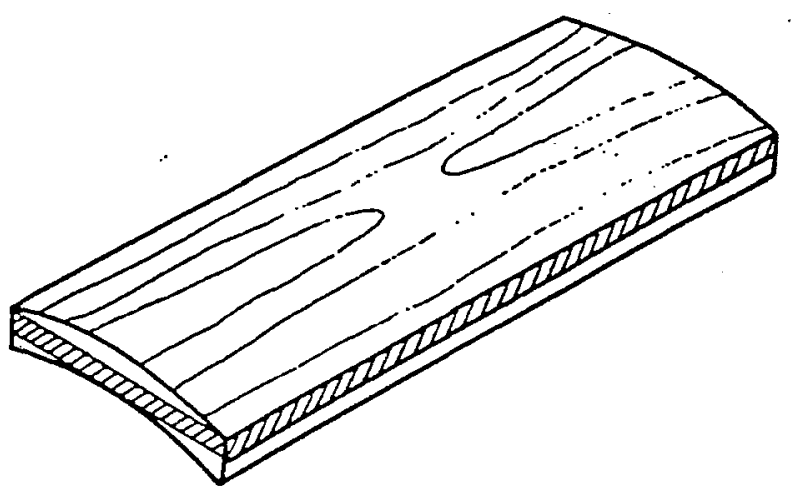

A - Abaulamento

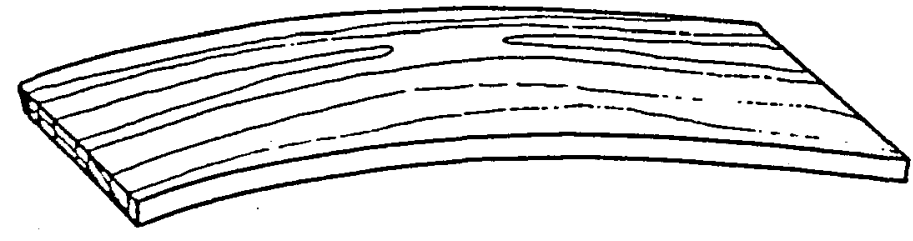

B - Encurvamento

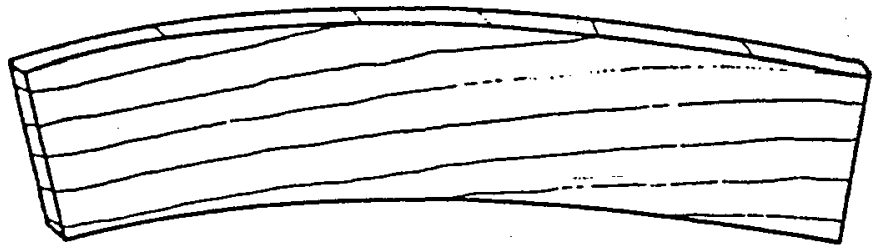

C - Arqueamento

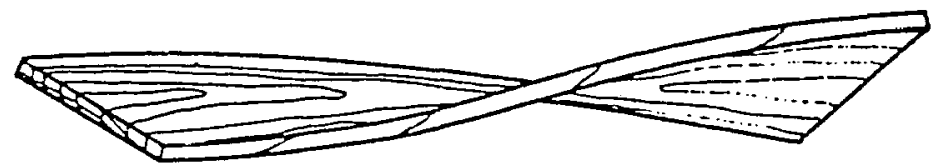

D - Torcimento

Figura 1 - Tipos de empenamentos da madeira (Ponce \& Watai, 1985). 
McMillen (1969) sugere que para evitar o problema das rachaduras a umidade relativa no início da secagem seja mantida o suficientẹmente alta para que a perda de umidade não seja tão acentuada. Deve-se manter a temperatura baixa até que toda a água capilar tenha sido retirada. Após esse instante, a umidade relativa pode ser abaixada e a temperatura elevada sem o risco de aparecimento de defeito.

Três tipos de rachaduras podem aparecer na madeira

durante a secagem:

rachaduras de topo: de acordo com Martins (1988), são rachaduras que ocorrem nos extremos das peças, causadas pela secagem rápida destas partes em relação ao resto. Neste caso, os extremos começam a contrair rapidamente e como o restante da peça não acompanha, ocorrem as rachaduras que, em casos mais sérios, podem transformar-se em verdadeiras fendas, causando grandes perdas de madeira.

rachaduras de superficie: são falhas que usualmente ocorrem nos raios da madeira, por toda a face lateral da peça, podendo, também, ocorrer nos dutos resiniferos (Rasmussen, 1961). Segundo Galvão \& Jankowsky (1985), estas rachaduras podem aparecer quando as condições de secagem são muito severas, isto é, baixas umidades relativas, provocando a rápida secagem das camadas superficiais até valores inferiores ao PSF, enquanto as camadas internas estão ainda com mais de $30 \%$ de umidade. Como as camadas internas impedem as superficies de se retraírem, aparecem tensões que, excedendo a resistência da madeira à tração perpendicular às fibras, provocam o rompimento dos tecidos lenhosos. 
rachaduras internas ou em favos de mel: de acordo com Ponce \& Watai (1985), estas rachaduras podem resultar de rachaduras superficiais, que se fecharam na superfície, ou podem ser o resultado de rupturas por tração no interior da peça. Em muitos casos, este tipo de defeito não é visível na superficie e no topo da peça, e somente após o processamento, poderá ser observado. Quando da incidência de rachaduras internas, estas não poderão ser eliminadas e, na grande maioria dos casos, a madeira não poderá ser utilizada (Oliveira, 1981).

Com relação ao encruamento ou endurecimento superficial, McMillen (1969), frisa que esse defeito é causado devido aos esforços de tração e compressão que ocorrem na madeira durante o processo de secagem.

Oliveira (1981) comenta que o encruamento é causado, basicamente, por secagem muito rápida e desuniforme. Uma secagem rápida dá madeira, com umidade superior ao PSF, faz com que as suas camadas externas atinjam rapidamente baixos valores de umidade. Em consequência, estas camadas ficam sob o efeito de esforços de tração, enquanto que a parte central, estando acima do PSF, não se retrai e fica sob compressão. Com a sequência da secagem, nas mesmas condições, a parte central passa a uma umidade menor que o PSF e começa a retrair-se. Entretanto, esta retração não é acompanhada pelas camadas externas, ocasionando a sua compressão. Essa situação permanece mesmo depois da madeira atingir um teor uniforme de umidade. $O$ processo de encruamento pode originar rachaduras internas, existindo, também, uma relação com rachaduras superficiais. 
O endurecimento superficial poderá ser eliminado se ao final da secagem a madeira for submetida a um tratamento com vapor (condicionamento) deixando-a exposta, por prolongados períodos de tempo, à elevadas umidades relativas.

\subsection{Processos de secagem mais utilizados}

a) Secagem ao ar

A secagem natural da madeira, ou secagem ao ar, consiste em reduzir o teor de umidade da madeira à um valor compatível com as condições climáticas, no menor espaço de tempo possível, evitando-se o aparecimento de defeitos resultantes da secagem (Gomide, 1973). É o método de secagem mais tradicional, sendo que a taxa ou velocidade de secagem não pode ser completamente controlada, dependendo em grande parte das condições ambientais (Tomaselli, 1979).

Segundo Carlos (1984), a secagem ao ar apresentam várias vantagens como :

não exige investimentos dispendiosos com equipamentos de secagem, manutenção e consumo de energia;

pode ser efetuada próxima ao local de extração ou desdobro;

pode-se combinar a secagem ao ar com a secagem artificial (pré-secagem). Essa prática torna a produção mais econômica, aumenta a produtividade $\mathrm{e}$ permite um melhor aproveitamento do secador. 
A secagem natural da madeira depende da temperatura, da umidade relativa do ar, da precipitação e da circulação do ar no interior da pilha construída com as peças de madeira a secar. Os fatores climáticos, por sua vez, são influenciados por condições locais, tais como elevações, topografia, drenagem do terreno e massas de água existentes nas proximidades (Gomide, 1973).

Portanto, podemos concluir que a taxa à qual a madeira secará ao ar depende de fatores que envolvem a própria madeira, condições climáticas e o pátio. Dentre esses fatores, o pátio de secagem é o mais facilmente controlável, tornando-se assim de grande importância para a secagem ao ar.

No pátio de secagem aspectos que merecem uma atenção especial são : o preparo das pilhas ( por espécies, dimensões, espessuras, etc ); as bases dessas pilhas, que devem permitir ventilação e distanciamento do solo; o espaçamenţo entre as pilhas ( que varia em função do clima e dos defeitos a serem evitados); os separadores; a proteção da madeira em secagem contra radiação solar e precipitação direta (Carlos, 1984).

Os defeitos podem ser reduzidos por um bom entabicamento e adequada confecção das pilhas (cobertura e pesos na camada superficial). Uniformidade na serraria, produzindo tábuas de igual espessura, é outro fator desejado,-que ajuda no controle dos defeitos.

c) Secagem convencional

A secagem convencional é aquela conduzida em estufa ou secador, constituído basicamente de uma câmara fechada, onde existe circulação de ar forçado, cuja temperatura e umidade relativa podem ser controladas (STPC, 1990). 
Segundo Jankowsky (1999), um secador convencional pode ser definido como o equipamento (câmara fechada) projetado para secagem de madeira serrada, com um sistema de aquecimento para operar a temperaturas entre $40^{\circ} \mathrm{C}$ e $90^{\circ} \mathrm{C}$, um sistema de ventilação para forçar o fluxo de ar através da pilha de madeira, um sistema de umidificação do ar e janelas que permitam a exaustão do ar saturado e admissão de ar externo (não saturado).

A temperatura e a umidade relativa dentro do secador são controladas de forma a manter as condições de acordo com o previsto no programa de secagem

Basicamente, os programas de secagem consistem numa sequência estudada de temperaturas e umidades relativas, visando reduzir rapidamente a umidade da madeira até um teor pré-determinado, com o menor número possível de defeitos (Galvão \& Jankowsky, 1985).

A escolha de um programa de secagem deve ser baseada nos padrões de qualidade desejados, tais como: defeitos admissíveis, teor de umidade final, grau de uniformidade e condição final de tensões internas das peças.

Em geral, as madeiras de folhosas, principalmente as mais densas, levam um tempo relativamente longo para secar e os defeitos de secagem e teor de umidade são críticos para muitos dos seus usos. Sendo assim, os programas de secagem são normalmente baseados em teor de umidade. Os programas em função de tempo (determinadas condições de temperatura e umidade relativa são praticadas por períodos de tempo pré-determinados) também podem ser utilizados quando a madeira idêntica é seca repetitivamente em mesmo tipo de secador (Ponce, 1985).

Segundo Galvão \& Jankowsky (1985), as principais vantagens da secagem convencional são: 
redução do período de secagem, possibilitando giro mais rápido do capital; maior controle sobre os efeitos da secagem; possibilidade de eliminar fungos e insetes; redução da umidade da madeira a teores previamente determinados, em qualquer época do ano;

eliminação da necessidade de grandes pátios requeridos para a secagem natural.

$O$ principal inconveniente da secagem em secador convencional é o alto investimento inicial, referente ao equipamento e à sua instalação. Porém, quando a produção de madeira é significativa e constante, o investimento em um secador torna-se a melhor alternativa econômica (Henriquez, 1986).

É importante salientar ainda que a secagem é considerada uma das fases mais importantes dentro da indústria madeireira, pois dela depende toda a programação da produção e agrega maior valor ao produto final (Jankowsky, 1998).

\subsection{A evolução da secagem da madeira nas indústrias de base florestal}

Nos países de tradição madeireira verifica-se um constante aprimoramento do maquinário usado para o processamento da madeira (Campanário \& Silveira, 1988).

No Brasil, a não atualização do parque industrial foi uma consequência da política de proteção a indústria local, através de restrições 
tributárias a importação de bens de capital. A abertura do mercado, no início dos anos 90, e a diminuição das alíquotas de importação, permitiu que muitas indústrias madeireiras adquirissem equipamentos de tecnologia mais atual.

Contudo, para que se possa efetuar uma análise adequada do nível de tecnologia aplicada pelas indústrias no presente, é importante uma visão histórica quanto ao desenvolvimento tecnológico em si. Mesmo com poucas informações disponíveis, é possivel acompanhar o que ocorreu ao longo das últimas décadas.

Por volta 1960, a Comissão Coordenadora de Exportação de Madeiras - CCEM, conforme cita Tomaselli (1974), verificou uma desmoralização do produto brasileiro na Europa, principalmente na Inglaterra e Alemanha, devido a desclassificação do material e falta de um sistema de controle de qualidade, diretamente ligadas ao fator secagem.

Parte do prestígio só foi reestabelecido em 1964. Sugeria-se a esta época uma intervenção estatal devendo incluir:

- medidas de incentivo à melhoria da qualidade da madeira serrada pelo combate aos fungos e carunchos, e introdução de processos de secagem artificial;

- redução do volume de imobilizações financeiras, obtendo-se flexibilidade em relação ao mercado por coordenação de programas de estocagem e reduções do estoque em todas as fases.

Posteriormente, um novo levantamento foi realizado por Tomaselli (1974), nos estados de Santa Catarina e do Paraná, que relatou os seguintes problemas :

- baixa qualidade dos equipamentos;

- inexistência de programa de secagem;

- baixo nível técnico dos operadores;

- pouca atenção dispensada pela administração à fase de secagem; 
inexistência de cálculos de custos relacionados à operação secagem; falta de critérios na escolha do equipamento.

Sugeria então, atitudes que deveriam ser tomadas a curto espaço de tempo, através de orgãos governamentais, associações de classe, e da própria indústria, afim de elaborar cursos de secagem para operadores, obter programas tecnicamente elaborados, incutir modificações nos equipamentos atualmente empregados e incentivar pesquisas e publicações relativas à secagem artificial.

Já no final da década de 70 e início da década de 80 ocorreu a expansão e consolidação dos cursos de Engenharia Florestal no Brasil. A formação do Engenheiro Florestal engloba também a industrialização, sendo o único profissional de engenharia cujas atribuições profissionais incluem, de forma específica, o desempenho de atividades referentes a "produtos florestais, sua tecnologia e sua industrialização" (CONFEA, 1987).

O resultado dessa evolução foi a especialização do corpo docente e a disponibilidade de profissionais melhor preparados para atuar junto as indústrias.

Como resultado do aumento na capacitação técnica, muitas das recomendações efetuadas por Tomaselli (1974) foram realizadas. Embora não coordenadas e ocorrendo de maneira esparsas, podem ser destacadas as seguintes iniciativas que visam desenvolver e transferir tecnologia para o setor produtivo:

realização de cursos de atualização e preparação destinados a operadores de secagem (nível técnico), por instituições como Laboratório de Produtos Florestais/IBAMA, Departamento de Ciências Florestais da ESALQ/USP, Instituto de Pesquisas Tecnológicas de São Paulo (IPT), Escola de Florestas/UFPr, dentre outros; 
publicações de trabalhos técnicos, voltados para programas de secagem Jankowsky (1997), Brandão (1989); identificação de madeiras - IBDF (1988), Manieri \& Chimelo (1989) ; processo de secagem em si - Galvão \& Jankowsky (1985), Ponce \& Watai (1985); dentre outros tópicos;

realização do CONGRESSO FLORESTAL BRASILEIRO em 1968, 1973, 1978, 1982, 1986, 1990 e 1993 , com sessões específicas para Tecnologia de Madeiras, onde é possível efetuar trocas de conhecimentos sobre a situação do setor madeireiro;

realização, por iniciativa da Associação Brasileira de Produtores de Madeira (ABPM), de seminários para discutir a tecnologia de processamento da madeira - SEMADER: Seminário sobre processamento e utilização de madeiras de reflorestamento,, realizados em 1984, 1988, 1992, 1996 e 1998;

criação de Centros Tecnológicos, por iniciativa do SENAI :

CETMO-NIT/MM - Centro Tecnológico do Mobiliário, em Bento Gonçalves/RS

CETMAM - Centro de Tecnologia da Madeira e do Mobiliário, em São José dos Pinhais /PR;

realização em 1998 e 1999, por iniciativa do IPEF - Instituto de Pesquisas e Estudos Florestais e do Departamento de Ciências Florestais da ESALQ/USP, do "Workshop sobre Secagem de Madeiras", criando um fórum de discussão e congregando a indústria madeireira, fornecedores de equipamentos $\mathrm{e}$ instituições de pesquisa. 
Nota-se claramente que nos últimos anos ocorreu uma evolução tecnológica, tanto pela incorporação de máquinas e equipamentos mais modernos como pelo aumento e aprimoramento técnico da força de trabalho do setor. Contudo, também destaca-se o fato de que esse desenvolvimento ocorreu de forma descoordenada, não existindo até o momento um estudo que permita avaliar o atual estágio tecnológico do setor.

Por outro lado, uma das principais características do segmento industrial de processamento mecânico da madeira é a predominância de micro e pequenas empresas, descapitalizada e operando com baixo nível técnico (Ponce, 1995).

No estado de São Paulo concentra-se uma grande porcentagem dessas indústrias, apesar da distância dos grandes centros produtores de madeiras.

Mais de $13 \%$ dos estabelecimentos e $16,4 \%$ de empregos no setor de madeira estão concentrados no estado de São Paulo. No setor mobiliário, São Paulo concentra mais de $29 \%$ de estabelecimentos e $41,4 \%$ da mão-de-obra, comprovando que o estado é um grande centro consumidor de madeiras e tem um grande centro produtor de manufaturados (Campanário \& Silveira, 1988).

Os equipamentos utilizados por essas empresas são antigos e ultrapassados. Em 45\% das empresas, a idade média dos equipamentos é de 6 a 10 anos, e em $38 \%$ o tempo de uso das máquinas é superior a 10 anos. Esse fato torna necessário um trabalho permanente de manutenção: $66 \%$ das empresas realiza reformas em seus equipamentos, mas apenas $23 \%$ possui setor de manutenção (Revista da Madeira, 1995).

Portanto, é importante chamar atenção para a importância do segmento, que engloba mais de 28 mil indústrias no país e emprega mais de meio milhão de pessoas, sendo 110 mil no estado de São Paulo. O setor comercial de 
madeiras poderá colaborar muito com o desenvolvimento harmônico da economia, desde que adequadamente conduzido através da aplicação dos princípios da ciência e tecnologia de madeiras (IBGE, 1996 e Revista da Madeira, 2000).

\subsection{Controle de qualidade}

A prática de Controle de Qualidade tem sido usada desde o início da atívidade industrial. Nos séculos XII e XIII, os profissionais que se ocupavam da fabricação de diversos produtos eram conhecidos como "mestres" e se reuniam em "corporações de oficio", que prescreviam os padrões de qualidade e produtividade. Com base na produtividade média e em normas bastante rígidas, fixavam o preço justo para os produtos (Cunha \& Bartholo, 1986).

Por volta do século XVIII, a revolução burguesa progressista liberou o antigo "mestre" do controle da corporação, implicando num aumento da produtividade em detrimento da qualidade.

$\mathrm{Na}$ indústria moderna, o controle de qualidade extrapolou sua definição formal - "Fiscalização sobre o conjunto de propriedades ou atributos de um determinado produto para evitar que se desviem dos padrões préestabelecidos"- abrangendo desde as definições estratégicas da empresa até o acompanhamento do uso pelo consumidor final. A mudança mais marcante não foi do conceito de controle de qualidade, mas sim na forma de aplicações desse conceito. Evolui-se de um conceito estático (simples inspeção) para um conceito dinâmico e interrelacionado (Jankowsky, 1988).

O embasamento para o controle de qualidade consiste em ter todos os profissionais da indústria conscientes, engajados e motivados para o 
desafio de simplificar, racionalizar e aumentar o desempenho. Consequentemente, ocorrerá a diminuição de perdas e rejeitos, que resultará em maior retorno financeiro. $\mathrm{Na}$ indústria madeireira não deve ser diferente, e ainda, procurar aliar ao controle de todo processo, pesquisas tecnológicas para evolução do setor.

No Brasil (Nahuz, 1988), a pesquisa tecnológica no setor madeireiro é praticada em institutos, laboratórios e centros de pesquisas ligados a orgãos governamentais federais, estaduais e municipais, universidades, e menos frequentemente, a empresa de grande porte. O controle de qualidade é uma das áreas de pesquisa mais importante. Essa área de pesquisa permite abranger todas os aspectos considerados importantes no setor madeireiro, que são :

matéria-prima e insumos, processamento, mão-de-obra operacional e gerencial.

A qualidade do produto final estará na dependência dos três fatores envolvidos na sua produção, anteriormente citados por Nahuz (1988), e qualquer falha em um desses fatores prejudicará o padrão de qualidade (Jankowsky, 1991).

A fim de atingir os seus objetivos, a empresa deve organizar o seu processo produtivo de forma que os fatores técnicos, administrativos e humanos, que afetam a qualidade e serviços estejam sob controle. Todo este controle deve ser orientado no sentido da redução, eliminação e, acima de tudo, prevenção de deficiências da qualidade (Macfarlane \& Castro, 1990).

Prevenção, reduz a mão de obra da classificação e separação do produto sem conformidade (fora do padrão), como também reduz a quantidade de rejeitos, material de segunda e material que necessita de um retoque; e ainda, diminui reclamações de clientes e em muitas empresas acaba com a maioria dos 
trabalhos referentes ao uso de equipamentos extras. Resumindo, o aumento da qualidade gera lucro maiores sem haver necessidade de se aumentar o preço do material, além de gerar um produto mais confiável o que facilita sua característica de marketing (Carson, 1958).

O sucesso da introdução de um determinado produto nos principais mercados internacionais, está baseado na satisfação dos seguintes requisitos: características da madeira, continuidade do abastecimento, preços competitivos e garantia. A qualidade de um produto madeireiro é afetado por fatores que vão desde a qualidade da tora até o processamento industrial empregado, passando pelo condicionamento e armazenamento (Zenid, 1989).

As serrarias brasileiras em seu maior número, estão acostumadas ao padrão de qualidade do mercado doméstico, que é reconhecidamente inferior ao dos mercados internacionais.

Segundo Jankowsky (1991), um ítem importante do controle de qualidade é a escolha do instrumento a ser usado para medir ou avaliar essa qualidade. Características subjetivas como tonalidade ou brilho de um acabamento podem ser avaliados com a adoção de padrões comparativos. Características mensuráveis devem ser quantificadas por instrumentos simples de usar, robustos, de fácil leitura e, principalmente, precisos.

É importante que o padrão dos instrumentos de medição seja o mesmo para operadores e inspetores, da mesma forma que moldes e gabaritos, sejam feitos com a mesma precisão dos instrumentos que irão avaliar a qualidade do produto.

Para o gerenciamento dessas fases há necessidade de profissionais capacitados para entender o funcionamento e contribuir para o êxito, participando ativamente de todas as etapas (Moll, 1990). A realização de inspeções contínuas não será eficaz se não existirem registros que permitam 
acompanhar flutuações ou tendências de variação da qualidade. Esses registros permitirão quantificar o custo das peças mal feitas ou do trabalho necessário para refazê-las, que pode ser utilizado também como um índice de qualidade (Jankowsky, 1988).

Um programa de controle de qualidade, para ser eficiente, tem que ser dinâmico, o que resulta na necessidade de revisões periódicas, visando avaliar seus beneficios, atualizar seus objetivos e determinar quais mudanças são importantes para aprimorar a qualidade dos produtos.

De acordo com Jankowsky (1991), para que se possa implantar um programa para o controle de qualidade é necessário que se faça primeiramente um levantamento para se verificar os principais problemas existentes na indústria, e daí planejar e administrar o controle de qualidade, o qual trará uma série de benefícios, como:

aumento da produtividade: quando um método é desenvolvido com a finalidade de se obter a melhor qualidade no produto, verifica-se que este é também o melhor método de trabalho, resultando em maior produtividade. Além disso, reduzindo-se as rejeições a um mínimo e com o esforço global para que todas as unidades produzidas atinjam os padrões de qualidade, tem-se a possibilidade de manter os programas de produção em seu pico;

custos unitários mais baixos: quando as rejeições são numerosas, os custos do material perdido e do trabalho para recuperar as unidades defeituosas podem representar uma parcela significativa do custo de fabricação. Com a avaliação do estágio atual da empresa e, consequentemente, com a implantação de um controle de qualidade implicará na "descoberta" de um melhor método de trabalho e menor número de rejeições; 
melhoria na moral dos empregados: se pretende com a execução do programa de controle de qualidade eliminar o tradicional conflito entre o pessoal da produção e a equipe de controle de qualidade através do envolvimento global dos recursos humanos;

melhor qualidade: como consequência final de todo o esforço na execução do programa de controle de qualidade tem-se a efetiva melhoria na qualidade do produto. Mais importante, permite ao empresário manter e assegurar o padrão de qualidade dos seus produtos.

Com relação a secagem de madeiras, o controle de qualidade deve ser feito antes, durante e depois da secagem. Antes da secagem ser iniciada, os defeitos já existentes na madeira devem ser avaliados, para comparar com a inspeção feita no final do processo. Assim, será possível constatar se o processo está provocando a ocorrência de algum defeito específico. (Jankowsky, 1995).

É recomendável também, quando possível, inspecionar a carga durante a secagem, procurando identificar os possíveis defeitos para que medidas corretivas sejam tomadas o mais rápido possível.

\subsection{Pesquisa de mercado}

Conforme cita Tagliacarne (1989), “pesquisa de mercado é o estudo dos problemas relativos à transferência e à venda de bens e serviços do produtor ao consumidor, e compreende as conexões e relações entre a produção e o consumo, a fabricação de produtos, sua distribuição e venda no atacado e 
varejo, juntamente com os seus aspectos financeiros. $O$ estudo consiste, especialmente, em coletar, analisar e interpretar as informações disponíveis como também coletar, analisar e interpretar elementos censitários da distribuição, elementos das pesquisas sobre consumo, examinar a contabilidade das empresas comerciais, etc."

Contudo, essa definição não é suficiente para indicar o verdadeiro conteúdo, importância e extensão das pesquisas de mercado. Insistem muito sobre a fase de distribuição e vendas, como se as pesquisas devessem intervir só após a fabricação do produto, quando, muitas vezes, elas são úteis antes da fabricação.

Para que um projeto de pesquisa de mercado seja o mais adequado possivel é necessário que se obtenha informações fazendo algum tipo de trabalho de campo. Em grande parte a pesquisa de mercado gira em torno de decisões e opiniões emitidas pelas pessoas (Livingstone, 1989).

Conforme sugere Marquesini (1995), para que o trabalho de campo seja realizado de forma racional, deverá ser desenvolvido de acordo com as seguintes fases:

- elaboração do questionário: a qualidade de uma pesquisa de mercado, executada com a mala direta ou com o método de entrevistas, em grande parte depende da eficiência do questionário compilado para a coleta de informações .

. essa fase deverá ser executada em duas fases distintas: $\left.1^{0}\right)$ teste piloto da pesquisa: essa fase deverá ser realizada para avaliar o questionário e introduzir as correções e adequações necessárias para o bom entendimento, por aqueles que o fossem responder. Evita-se, desse modo, introduzir modificações no questionário, posteriormente, quando a pesquisa já estiver sendo aplicada. $2^{\mathbf{o}}$ ) adequação do questionário : como 
resultado do teste-piloto da pesquisa, deverá identificar as alterações passíveis de serem introduzidas no questionário.

seleção da indústria para pesquisa: se a população total sobre a qual deve ser feita a pesquisa de mercado for pequena, será possível levar a cabo um levantamento de todas as unidades existentes nesse universo. Normalmente, será preciso fazer uma escolha, isto é, empregar um método amostral. A amostra é, portanto, um método de obter informações sobre a população total a partir do exame de pequena parte desse universo .

Em termos aproximados, a pesquisa de mercado voltada para o consumidor aproxima-se mais do método de amostragem aleatória e a pesquisa de mercado industrial aproxima-se mais de uma situação tendenciosa onde as técnicas estatísticas convencionais terão de ser abandonadas e cada problema tratado separadamente (Livingstone, 1989).

aplicação da pesquisa: se faz necessário contactar a pessoa responsável ou com o maior conhecimento possível sobre o assunto em cada indústria. A coleta de informações deve ser a mais cuidadosa possível e há necessidade, às vezes, de insistência com relação as respostas dos entrevistados para que sejam precisos e recordem exatamente, por exemplo, dos tipos de material comprado (Tagliacarne, 1989).

tabulação e análise dos resultados: fase em que será realizado o agrupamento das informações previamente selecionadas, avaliando os aspectos prédeterminados. 


\section{MATERIAL E MÉTODOS}

Considerando que o objetivo foi realizar um diagnóstico das condições operacionais da secagem convencional de madeiras no estado de São Paulo, o presente trabalho envolveu, principalmente, o levantamento de informações junto as indústrias. A Figura 2 apresenta um resumo da sequência metodológica adotada.

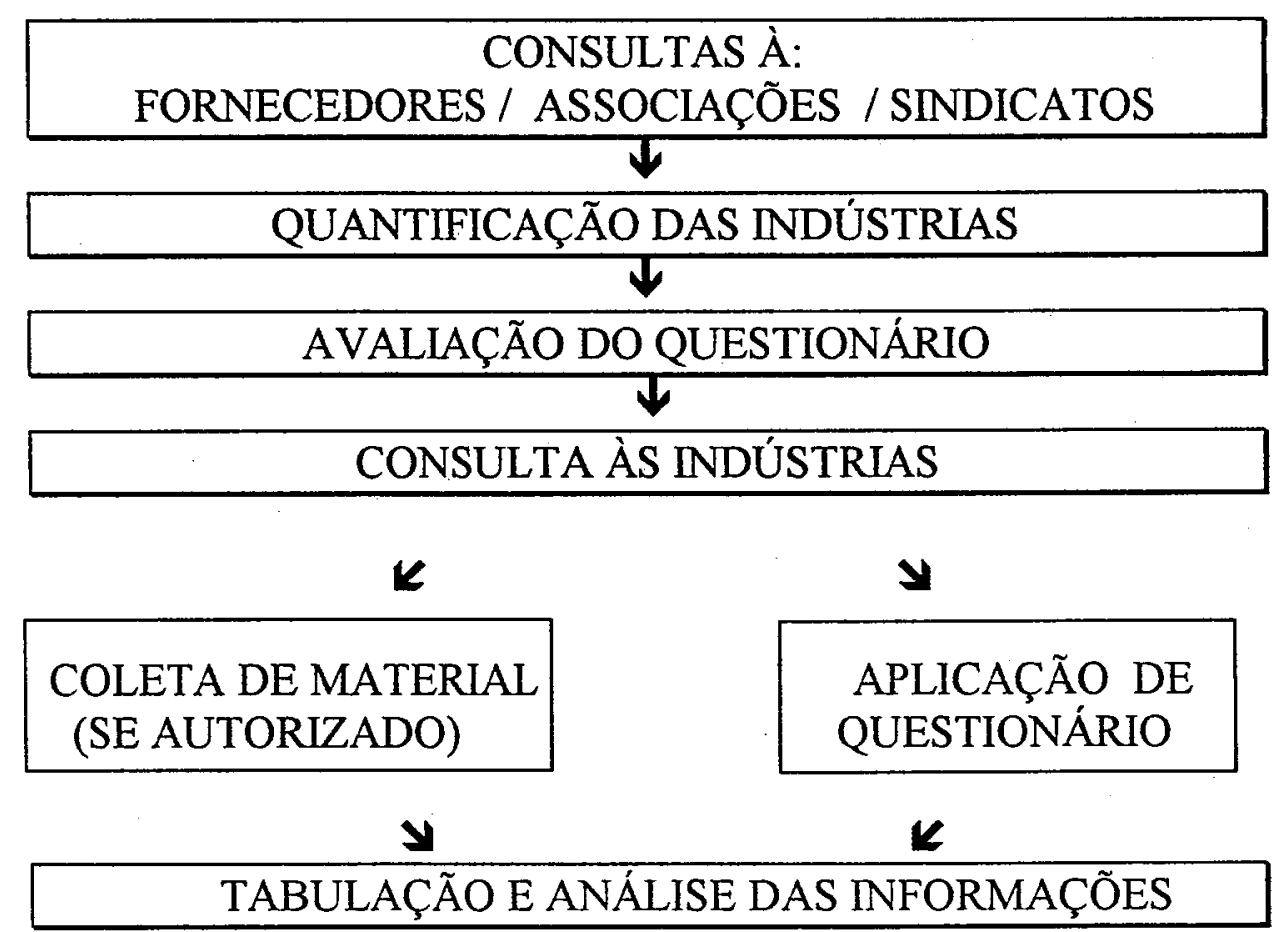

Figura 2 : Esquema resumido da metodologia. 


\subsection{Quantificação e qualificação das indústrias (universo de trabalho)}

Através de contatos e consultas à fornecedores de maquinário para indústrias madeireiras, foi possivel quantificar os secadores convencionais em operação ou temporariamente desativados; assim como a localização das indústrias e a capacidade estimada de secagem.

\subsection{Avaliação do questionário}

O questionário para orientar a coleta de informações foi elaborado com base na literatura, visando ser o mais abrangente possivel.

Para avaliar a viabilidade de executar o trabalho de campo, esse questionário foi aplicado em uma única indústria, sendo que o entrevistado também pode opinar sobre o questionário em si.

Assim, foi possivel quantificar o esforço necessário para a coleta em campo e definir o modelo definitivo do questionário.

\subsection{Consulta às indústrias}

As indústrias que possuem secadores convencionais foram contatadas inicialmente por telefone, para dar início a pesquisa, solicitar a colaboração no fornecimento de informações e agendar (autorização) uma visita. Quando não foi possivel agendar um contato pessoal, a coleta das informações básicas foi feita por correspondência. 
No contato pessoal a aquisição das informações constou da aplicação do questionário básico (Anexo $\mathrm{A}$ ), e englobou aspectos relativos à administração, ao produto (produção, tipo de madeira e consumo), ao equipamento (marca, capacidade e eficiência) e ao processo (nível técnico dos operadores e programas utilizados).

Por ocasião da visita solicitava-se a oportunidade de conhecer a linha de produção e, mais importante, autorização para coleta de material.

As indústrias que concordaram com a coleta na linha de produção foram, então, visitadas novamente. Nessa oportunidade foi realizado o levantamento em campo e a amostragem para testes em laboratório.

\subsection{Levantamento em campo}

Em inspeção na linha de produção foram feitas avaliações e medições seguindo o padrão do questionário completo (Anexo B), detalhando os seguintes aspectos:

características dos secadores, como construção, procedência, forma de carregamento, capacidade útil e sistema de controle;

procedimentos rotineiros do controle de processo, ou seja, existência de programas, conhecimento técnico dos operadores, execução e acompanhamento da secagem, testes de qualidade, quantificação de defeitos e registro das operações; 
qualidade do empilhamento, envolvendo medições da espessura dos separadores e da madeira (com paquímetro), e da distância entre tabiques (com trena). Essas medições foram feitas em todas as pilhas que compunham uma carga para secagem;

quantificação de defeitos por análise visual em cerca de $15 \%$ da peças de uma carga de madeira seca. Foi registrada a presença do defeito (encanoamento, abaulamento, arqueamento, torcimento e colapso), e posterior quantificação percentual da incidência de cada defeito em relação ao total de peças inspecionadas.

\subsection{Amostragem e testes em laboratório}

A amostragem do material destinado aos testes de qualidade em laboratório, levou em consideração o sistema do carregamento do secador.

Nos secadores carregados por empilhadeiras, em que a carga é composta de várias pilhas e o número de pilhas é proporcional a capacidade do secador, a amostragem teve como base a própria pilha de madeira, abrangendo a carga total de cada secador.

Para os secadores de vagonete, em que a carga é constituída de uma única pilha, o comprimento do secador foi dividido em seis partes iguais e a largura em 2, totalizando 12 partes. Cada duodécima parte da carga foi considerada como sendo uma pilha para efeito de amostragem.

De cada pilha foram retiradas 6 amostras, sendo 2 no terço superior, 2 no terço médio e 2 no terço inferior. 
O comprimento da amostra foi fixado em $30 \mathrm{~cm}$ (no sentido das fibras), retirada no meio da peça amostrada. A largura e a espessura, assim como a espécie, variaram em função do tipo de madeira que estava sendo industrializada. Logo após o corte, as amostras foram identificadas, embaladas em plástico para evitar alterações no teor de umidade e transportadas para o laboratório de secagem do Departamento de Ciências Florestais (ESALQ - USP).

Em laboratório foram feitos os ensaios para determinação da umidade média, distribuição de umidade entre e dentro das peças e do nível de tensões residuais, seguindo a metodologia tradicional para avaliação da qualidade da madeira seca, descrito em manuais de secagem (Rasmussem, 1961; Galvão \& Jankowsky, 1985; dentre outros).

Os teores de umidade foram determinados pelo método gravimétrico, onde as amostras úmidas são submetidas à secagem em estufa à $103^{\circ} \mathrm{C} \pm 2$ até massa constante. $\mathrm{O}$ teor de umidade é calculada com auxílio da equação 1 .

$U=\left(\frac{m u}{m s}-1\right) * 100$

Onde:

$$
\begin{aligned}
& \mathrm{U}=\text { teor de umidade }(\%) \\
& \mathrm{mu}=\text { massa úmida da amostra }(\mathrm{g}) \\
& \mathrm{ms}=\text { massa seca da amostra }(\mathrm{g})
\end{aligned}
$$


As Figuras 3 e 4 mostram, respectivamente, a retirada das amostras e a classificação das tensões residuais. Para verificação do teor e distribuição de umidade foram empregadas as amostras A e B, e para as tensões, foi utilizada a amostra $\mathrm{C}$.

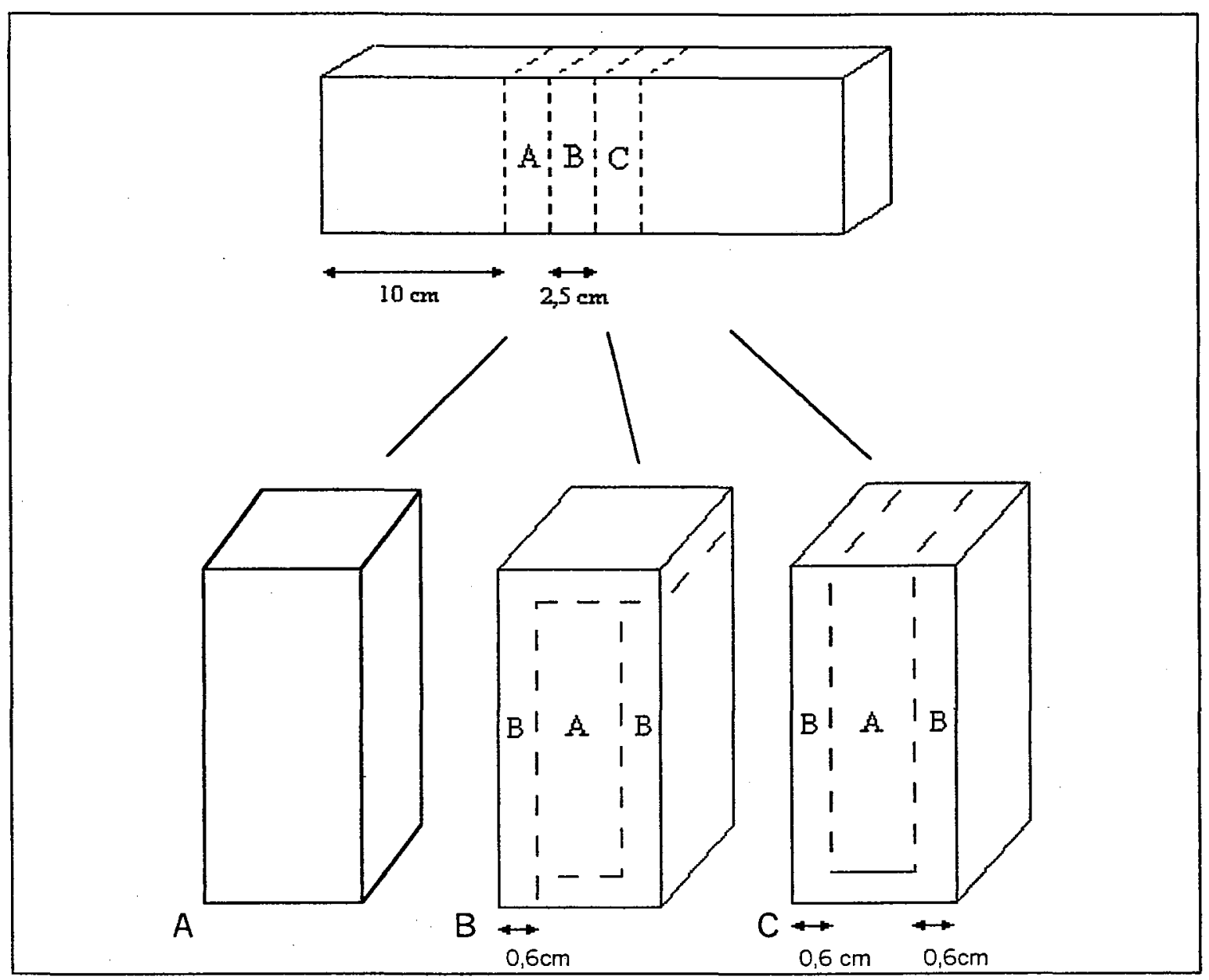

Figura 3 - Retirada dos corpos de prova para os testes de qualidade em laboratório (Rasmussen, 1961 e Ciniglio, 1998). 


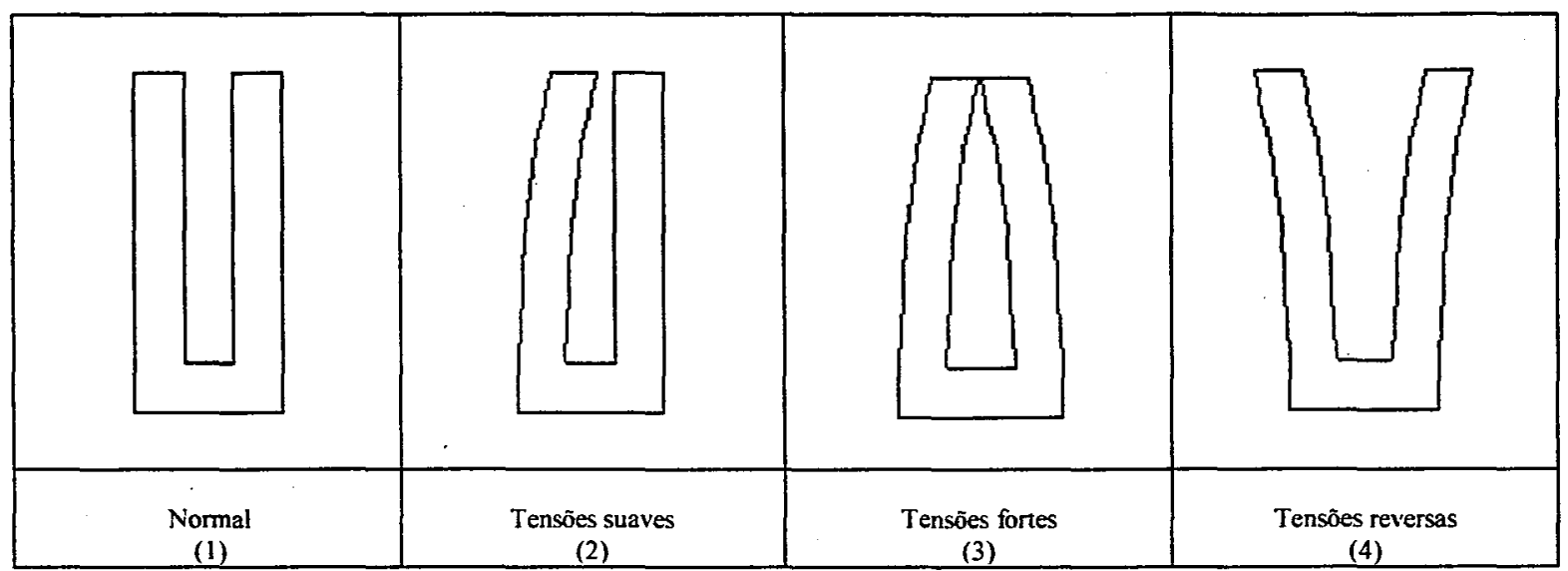

Figura 4 - Classificação das tensões (adaptada de Pratt, 1974 e Ciniglio, 1998).

\subsection{Análise dos resultados}

O conjunto das informações coletadas (questionários, observações em campo e análises em laboratório) foi tabulado de forma a possibilitar a qualificação e/ou quantificação dos seguintes aspectos:

aspectos gerais, buscando definir o perfil do setor madeireiro em relação a secagem convencional;

equipamentos (secadores convencionais e sistemas de controle);

nivel técnico dos operadores (recursos humanos);

espécies utilizadas, comparação percentual entre folhosas e coníferas, e possível relação do padrão da indústria com o produto final;

perfil das indústrias que autorizaram a coleta de material na linha de produção; preparação da madeira para secagem e seu possível efeito na qualidade do produto;

qualidade do produto madeira seca e incidência dos defeitos de secagem. 


\section{RESULTADOS E DISCUSSÃO}

\subsection{Aspectos gerais}

A partir das informações de fornecedores e associações foram localizadas 43 indústrias usando secadores convencionais, distribuídas em 31 cidades do estado de São Paulo, como mostrado na Figura 5. Foi identificada a existência de 121 secadores (câmaras) de 13 diferentes marcas, representando uma capacịdade instalada da ordem de $6.835 \mathrm{~m}^{3} \mathrm{e}$ uma produção mensal em torno de $24.000 \mathrm{~m}^{3}$ de madeira seca.

$\mathrm{O}$ número de indústrias praticando a secagem convencional representa $0,7 \%$ do total de indústrias do setor madeira/mobiliário instaladas no estado de São Paulo; que é estimado em cerda de 6000 empresas, de acordo com os dados do IBGE (1996) e Campanário \& Silveira (1988).

Mesmo admitindo que a presente pesquisa não tenha identificado todas as indústrias que praticam a secagem convencional, é possível concluir que esse número é muito pequeno.

Na Tabela 1 é apresentado a capacidade instalada de secadores convencionais e da produção mensal equivalente, comparando a situação do estado de São Paulo com os estados Norte-americanos em que predomina a secagem da madeira de folhosas pelo método convencional (Boone, 1995). 

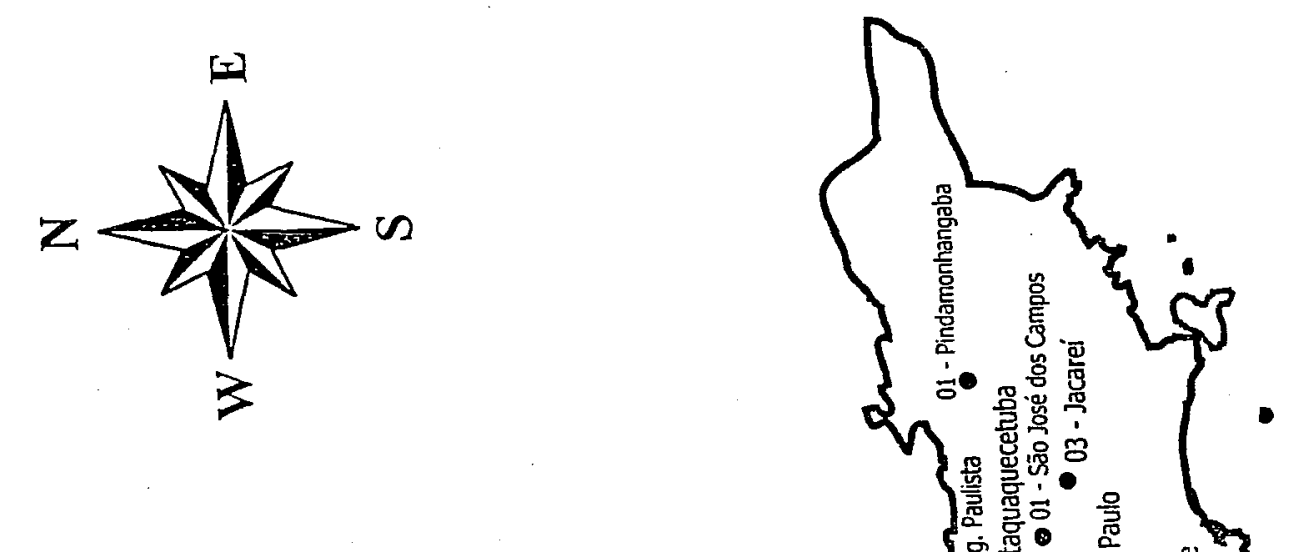
Tabela 1 - Comparação da capacidade de secagem convencional do estado de São Paulo com estados Norte-Americanos.

\begin{tabular}{ccc}
\hline Estado & $\begin{array}{c}\text { Produção mensal } \\
\left(\mathbf{1 0 0 0} \mathbf{~ m}^{\mathbf{3}}\right)\end{array}$ & $\begin{array}{c}\mathbf{N}^{0} \text { de câmaras } \\
\text { (secador convencional) }\end{array}$ \\
\hline Tennessee $\left({ }^{*}\right)$ & 102,1 & 359 \\
\hline Pennsylvania $\left(^{*}\right)$ & 74,3 & 419 \\
\hline Kentucky $\left(^{*}\right)$ & 58,1 & 174 \\
\hline New York $\left({ }^{*}\right)$ & 51,3 & 294 \\
\hline Ohio $\left(^{*}\right)$ & 44,0 & 208 \\
\hline São Paulo & 24,0 & 121 \\
\hline
\end{tabular}

(*) Boone, 1995.

Apesar do estado de São Paulo ser considerado como um dos maiores centros de produção e consumo do país, fica claro que a prática da secagem convencional não é comparável com a indústria norte-americana. É importante destacar, para validar a comparação, que a tabela exclui valores da secagem a alta temperatura; prática comum nos Estados Unidos para secagem da madeira de coniferas.

A baixa disseminação da secagem convencional no estado de São Paulo pode ser explicada pela indisponibilidade de capital para investimento.

De acordo com a Revista da Madeira (1995), o setor madeira/mobiliário é composto, em sua maioria, por indústrias com até 20 funcionários (77\% do total). A limitação das micro e pequenas indústrias para investimentos em máquinas e atualização tecnológica é agravada, no que se refere a secagem convencional, pelos próprios fornecedores que não ofertam câmaras de secagem para pequenos volumes de madeira. 


\subsubsection{Equipamentos}

Foram identificadas, atuando no mercado brasileiro, 21 empresas que ofertam secadores convencionais, seja como fabricantes ou representantes comerciais. Dentre elas 9 são de fabricantes nacionais e 12 de fornecedores estrangeiros.

No estado de São Paulo estão construídos secadores de 13 fornecedores (marcas) diferentes, sendo 8 brasileiros e 5 estrangeiros, como descrito na Tabela 2 .

Tabela 2 - Características dos secadores em operação no estado de São Paulo.

\begin{tabular}{ccccc}
\hline Procedência & Marca & Construcão & Ventilação & Carregamento \\
\hline Brasil & A & Alvenaria & $\begin{array}{c}\text { Superior central ou } \\
\text { Central }\end{array}$ & Empilhadeira ou vagonete \\
\hline Brasil & B & $\begin{array}{c}\text { Alvenaria ou } \\
\text { aluminio }\end{array}$ & Superior ou Lateral & Empilhadeira ou vagonete \\
\hline Brasil & $\mathrm{C}\left(^{*}\right)$ & Alvenaria & Superior e lateral & Empilhadeira \\
\hline Brasil & D $\left(^{*}\right)$ & Aluminio & Superior & Vagonete \\
\hline Brasil & E & Alvenaria & Superior & Vagonete \\
\hline Brasil & $\mathrm{F}$ & Alvenaria & Superior & Vagonete \\
\hline Brasil & $\mathrm{G}$ & Alvenaria & Superior & Empilhadeira \\
\hline Brasil & $\mathrm{H}\left(^{*}\right)$ & Alvenaria & Superior & Empilhadeira \\
\hline Portugal & $\mathrm{I}$ & Alumínio ou & Superior & Empilhadeira \\
\hline Alven./alum. & $\begin{array}{c}\text { Alumínio ou } \\
\text { Alven./alum. }\end{array}$ & $\mathrm{J}$ & Superior & Empilhadeira ou vagonete \\
\hline EUA & $\mathrm{K}$ & Alven./alum. & Superior & Vagonete \\
\hline Alemanha & $\mathrm{L}$ & Alven./alum. & Superior & Empilhadeira ou vagonete \\
\hline Itália & $\mathrm{M}$ & $\begin{array}{l}\text { Aluminio ou } \\
\text { Alven./alum. }\end{array}$ & Superior & Empilhadeira ou vagonete \\
\hline
\end{tabular}

$\left(^{*}\right)$ Não mais comercializadas. 
As informações contidas na Tabela 3 mostram a participação percentual de cada marca de secador por quantidade de câmaras, capacidade total instalada $\left(\mathrm{m}^{3}\right)$ e por quantidade de indústrias. A distribuição por capacidade e forma de carregamento consta da Tabela 4.

Tabela 3 - Distribuição dos secadores convencionais no estado de São Paulo.

\begin{tabular}{|c|c|c|c|c|c|c|}
\hline Marca & $\begin{array}{l}\text { Quantidade } \\
\text { de câmaras }\end{array}$ & $\%$ & $\begin{array}{c}\text { Capacidade } \\
\left(\mathbf{m}^{3}\right)\end{array}$ & $\%$ & $\begin{array}{c}\text { Quantidade de } \\
\text { indústrias }\end{array}$ & $\%$ \\
\hline $\mathrm{A}$ & 40 & 33,1 & 2151 & 31,5 & 5 & 10,2 \\
\hline $\mathrm{B}$ & 34 & 28,1 & 1765 & 25,8 & 20 & 40,8 \\
\hline$E$ & 7 & 5,8 & 1005 & 14,7 & 2 & 4,1 \\
\hline $\mathrm{F}$ & 4 & 3,3 & 136 & 2,0 & 4 & 8,2 \\
\hline C & 3 & 2,5 & 162 & 2,4 & 2 & 4,1 \\
\hline $\bar{G}$ & 3 & 2,5 & 105 & 1,5 & 1 & 2,0 \\
\hline $\mathrm{H}$ & 3 & 2,5 & 21 & 0,3 & 1 & 2,0 \\
\hline $\mathrm{D}$ & 2 & 1,7 & 60 & 0,9 & 1 & 2,0 \\
\hline Nacionais & 96 & 76,9 & 5405 & 79,1 & 36 & 71,4 \\
\hline $\mathrm{M}$ & 10 & 8,3 & 490 & 7,2 & 4 & 8,2 \\
\hline I & 6 & 5,0 & 270 & 3,9 & 3 & 6,1 \\
\hline $\mathrm{L}$ & 4 & 3,3 & 450 & 6,6 & 3 & 6,1 \\
\hline $\mathrm{J}$ & 3 & 2,5 & 120 & 1,7 & 2 & 4,1 \\
\hline $\mathrm{K}$ & 2 & 1,7 & 100 & 1,5 & 1 & 2,0 \\
\hline Estrangeiras & 25 & 23,1 & 1430 & 20,9 & 13 & 28,6 \\
\hline Total & 121 & 100 & 6835 & 100 & 43 & 100 \\
\hline
\end{tabular}

${ }^{*}$ ) Algumas indústrias possuem secadores de 2 ou mais marcas diferentes.

Tabela 4 - Distribuição dos secadores convencionais no estado de São Paulo, de acordo com a capacidade e a forma de carregamento.

\begin{tabular}{ccccc}
\hline Característica & \multicolumn{2}{c}{ Capacidade $\left(\mathbf{m}^{\mathbf{3}}\right)$} & \multicolumn{2}{c}{ Forma de carregamento } \\
\cline { 2 - 5 } observada & Até 60 & Acima de 60 & Vagonete & Empilhadeira \\
\hline No de câmaras & 86 & 35 & 59 & 62 \\
\hline$\%$ & 71,1 & 28,9 & 48,8 & 51,2 \\
\hline
\end{tabular}


As Figuras 6, 7 e 8 mostram uma melhor ilustração das formas de construção e de sistemas de carregamento dos secadores convencionais encontrados no estado de São Paulo.

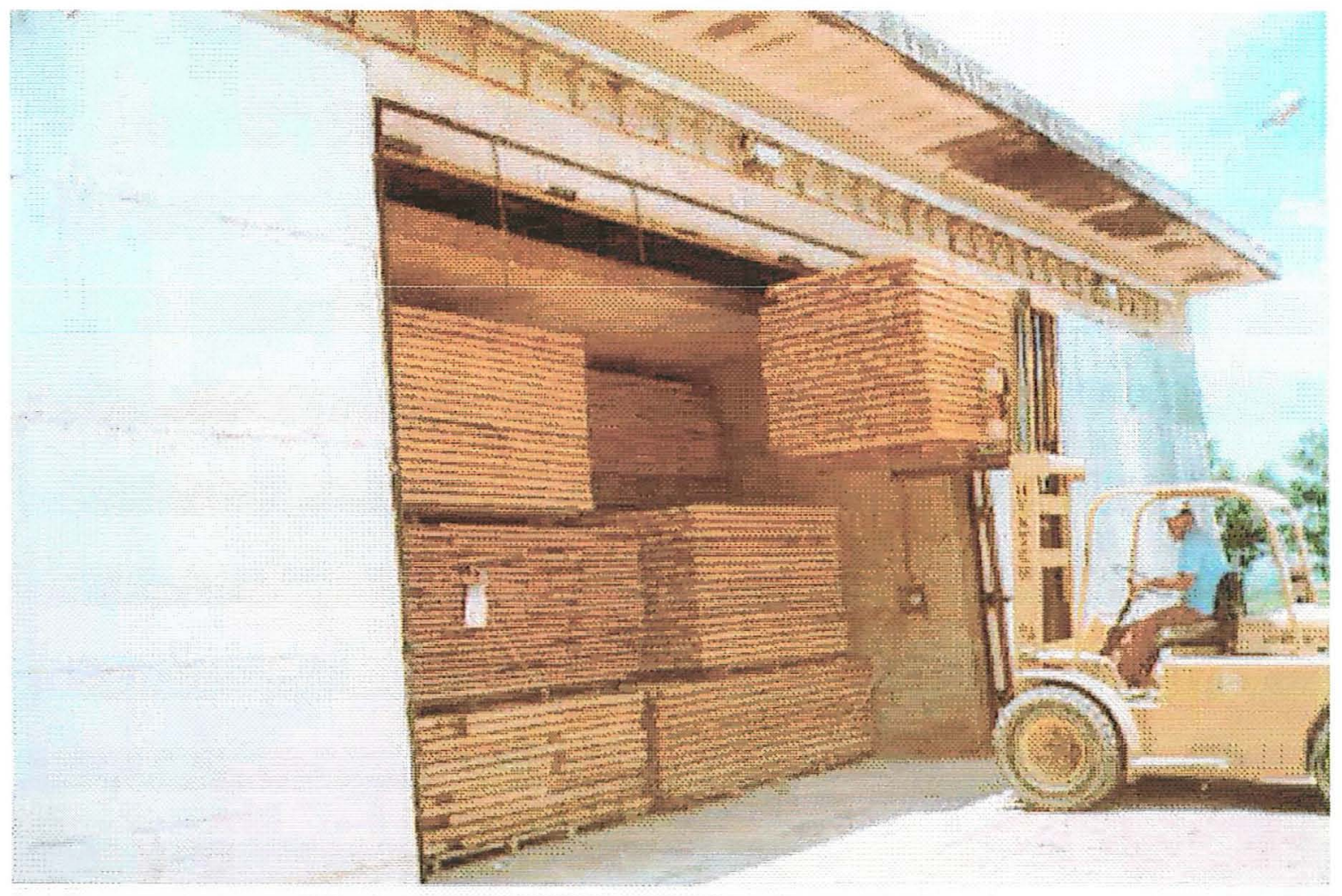

Figura 6 - Secador construído em alvenaria e carregado por empilhadeira. 


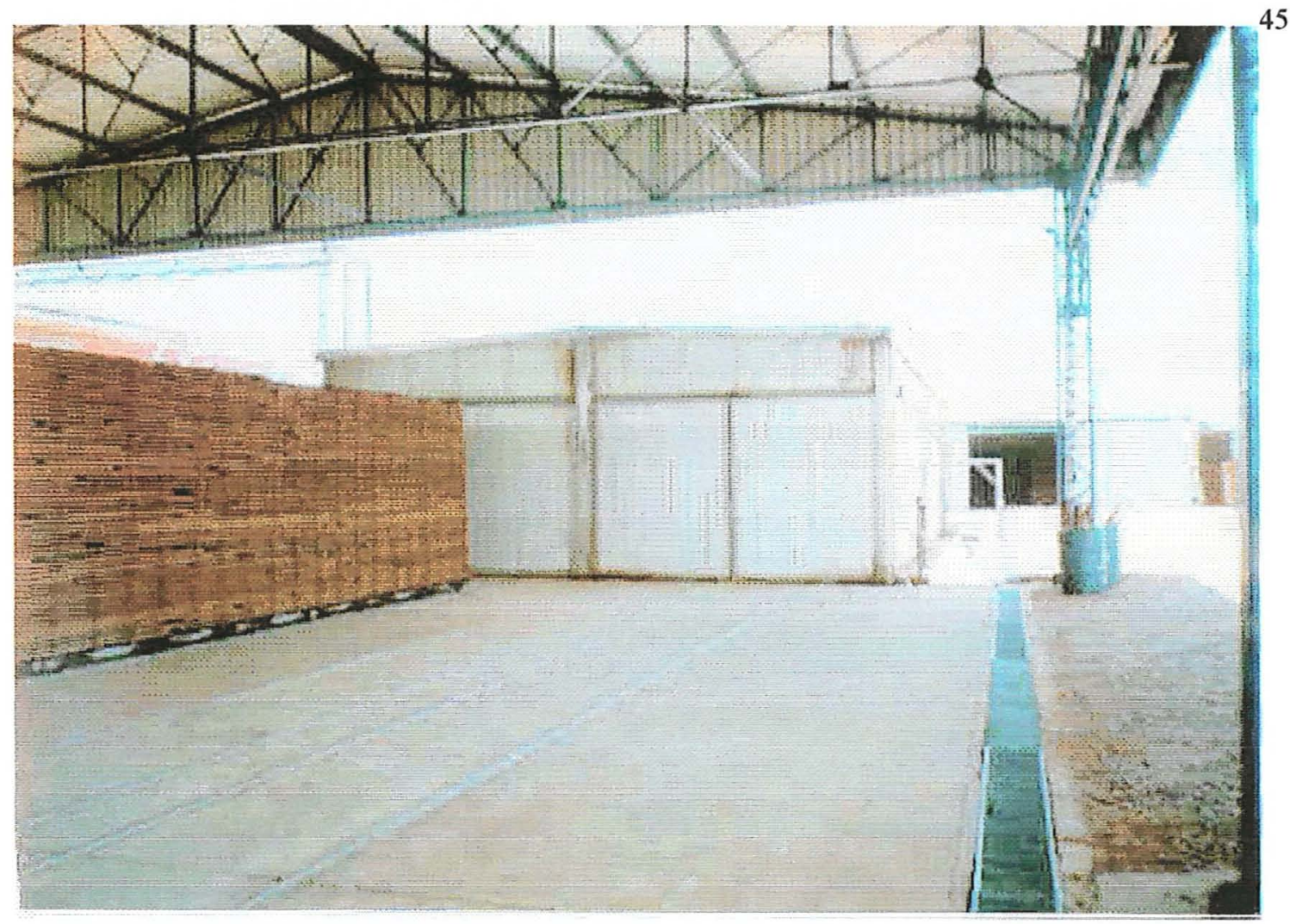

Figura 7 - Secador carregado por vagonete e construído totalmente em alumínio.

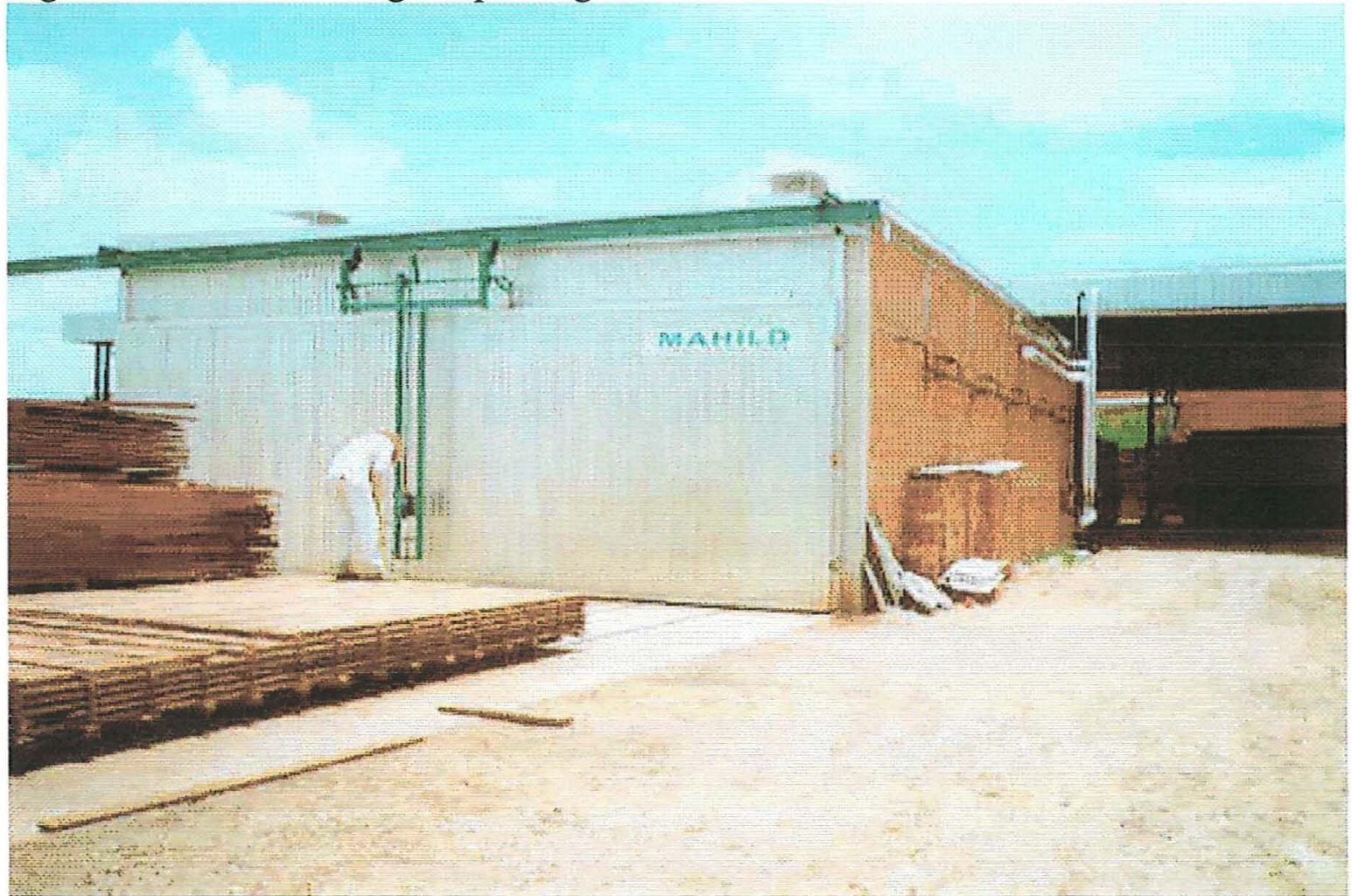

Figura 8 - Secador construído em alvenaria (paredes) e alumínio (outros componentes), carregado por vagonetes. 
Basicamente os secadores convencionais que existem no mercado tem a mesma configuração. As diferenças estão na qualidade do material de construção e nas características que melhor se ajustam a indústria.

Com base nas informações das Tabelas 2 a 4, verifica-se que predominam os secadores de fabricação nacional, construídos em alvenaria, com ventilação superior e com capacidade de secagem inferior a $60 \mathrm{~m}^{3}$. Não existe predominância apenas em relação a forma de carregamento.

O padrão do secador mais comum reflete a conjuntura tecnológica e econômica da indústria madeireira. Até 1990 as alíquotas de importação inviabilizavam a aquisição de máquinas e equipamentos no exterior. Os secadores mais acessíveis no mercado interno eram aqueles de construção em alvenaria e para volumes de madeira entre 25 e $40 \mathrm{~m}^{3}$.

Adicionalmente, a reduzida capacidade de investimento da indústria madeireira não estimulava os fornecedores locais para aprimorar seus equipamentos. Esta descrição é comprovada na informações da Tabela 3. A marca denominada " $A$ ", com $33,1 \%$ do total de câmaras em operação, são secadores de fabricação caseira.

Com o objetivo de reduzir o investimento necessário, a indústria madeireira providencia a construção da câmara em alvenaria e adquire as partes metálicas (ventiladores, trocadores de calor e portas) de fornecedores não tradicionais, "construindo" seu próprio secador.

Esse comportamento, além de gerar secadores, em muitos casos, de eficiência abaixo do desejável, também contribui para retardar o desenvolvimento tecnológico dos fornecedores nacionais. 
Tabela 5 - Secadores convencionais construídos antes e após 1990, no estado de São Paulo.

\begin{tabular}{ccccc}
\hline Origem & \multicolumn{2}{c}{$\begin{array}{c}\text { Câmaras } \\
\text { construídas }\end{array}$} & \multicolumn{2}{c}{ Capacidade total $\left(\mathbf{m}^{\mathbf{3}}\right)$} \\
& Até 1990 & Após 1990 & Até 1990 & Após 1990 \\
\hline Brasileira & 80 & 16 & 4393 & 1012 \\
\hline Estrangeira & 2 & 23 & 100 & 1330 \\
\hline Total & $\mathbf{8 2}$ & $\mathbf{3 9}$ & $\mathbf{4 4 9 3}$ & $\mathbf{2 3 4 2}$ \\
\hline
\end{tabular}

Como pode ser verificado na Tabela 5, após a abertura do mercado, com a redução da alíquota de importação, houve um aumento da concorrência e maior participação dos equipamentos importados. A proporção dos secadores nacionais para os importados, que era de 40,0:1,0 anteriormente, passou a ser de 0,7:1,0 após 1990 . Em relação a capacidade total instalada, essa mesma proporção decresceu de 44,0:1,0 para $0,8: 1,0 \mathrm{~m}^{3}$.

Observa-se que a capacidade média dos secadores construídos após 1990 é praticamente a mesma entre o equipamento nacional $\left(63,2 \mathrm{~m}^{3}\right)$ e o estrangeiro $\left(57,8 \mathrm{~m}^{3}\right)$, comprovando o padrão predominante em relação ao tamanho do secador. Cabe o comentário que, apesar da disponibilidade de informações técnicas e de técnicos capacitados, a indústria mantêm o hábito de investir por volume; sendo raros os empresários que contratam uma análise técnica para definir o modelo e a capacidade mais adequados a sua estratégia industrial.

Segundo Lausch (1998), a maior porcentagem de equipamentos estrangeiros construídos nos últimos anos se deve principalmente a melhor qualidade do material de construção e ao menor consumo energético, mesmo com a desvantagem do custo inicial maior.

A concorrência representada pelo fornecedor estrangeiro, ofertando um equipamento tecnologicamente mais atualizado, forçou o 
aprimoramento do produto nacional. Embora tenham perdido parte do mercado, os fabricantes locais estão reagindo, disponibilizando secadores mais eficientes e usando materiais de maior durabilidade.

\subsubsection{Recursos humanos}

Em relação aos operadores responsáveis pelo processo de secagem não se observa a mesma evolução ocorrida com os secadores, conforme pode ser visualizado na Tabela 6 .

Tabela 6 - Qualificação dos recursos humanos envolvidos na operação de secagem.

\begin{tabular}{cccc}
\hline Responsável pela secagem & $\begin{array}{c}\text { Funcionário } \\
(\%)\end{array}$ & $\begin{array}{c}\text { Proprietário } \\
(\%)\end{array}$ \\
\cline { 2 - 4 } & & 62,5 & 37,5 \\
\hline Grau de & $1^{\mathrm{o}}$ grau & 75 & 14 \\
\cline { 2 - 4 } instrução & $2^{\mathrm{o}}$ grau & 20 & 43 \\
\cline { 2 - 4 } & $3^{\mathrm{o}}$ grau & 5 & 43 \\
\hline
\end{tabular}

É importante ressaltar que $37,5 \%$ dos operadores, responsáveis pelo processo de secagem nas indústrias do estado de São Paulo, são os proprietários. Está é uma característica da pequena indústria, em que o dono assume a execução das atividades que considera mais importantes ou para as quais não conta com recursos humanos devidamente capacitados.

Em 1995 a Revista da Madeira informou que 70\% da mãode-obra no setor madeira/mobiliário, no estado de São Paulo, era de funcionários com primeiro grau. Apesar da área de secagem exigir mão-de-obra especializada, o trabalho da presente pesquisa chegou a valores bem próximos ao informado pela 
revista (75\%), quando considerados apenas os operadores contratados como funcionários.

Uma vez que melhorar os padrões de produtividade e de qualidade requer, necessariamente, recursos humanos devidamente qualificados; comprova-se que o treinamento (qualificação) da força de trabalho ainda é uma prioridade para a indústria madeireira.

\subsubsection{Espécies utilizadas}

O volume mensal de madeira seca pelo processo convencional no estado de São Paulo é da ordem de $24.000 \mathrm{~m}^{3}$, sendo que $79,4 \%$ do total $\left(19.045 \mathrm{~m}^{3}\right)$ são representados por espécies de coniferas (reflorestamento), principalmente do gênero Pinus (Tabela 7). No entanto, o setor apresenta uma quantidade maior de indústrias (27) trabalhando com madeiras de folhosas tropicais.

Tabela 7 - Distribuição das espécies secas pelo método convencional.

\begin{tabular}{ccccc}
\hline Madeiras & $\begin{array}{c}\text { Quantidade } \\
\text { de indústrias }\end{array}$ & $\begin{array}{c}\text { Quantidade } \\
\text { de espécies }\end{array}$ & \multicolumn{2}{c}{ Volume mensal } \\
\cline { 5 - 6 } $\begin{array}{c}\text { Reflorestamento } \\
\text { (coniferas) }\end{array}$ & 19 & 3 & 19.045 & $\%$ \\
\hline $\begin{array}{c}\text { Reflorestamento } \\
\text { (eucalipto) }\end{array}$ & 3 & 1 & 70 & 0,3 \\
\hline $\begin{array}{c}\text { Nativas } \\
\text { (folhosas) }\end{array}$ & 27 & 27 & 4864 & 20,3 \\
\hline Total & $\mathbf{4 3}$ & $\mathbf{3 1}$ & $\mathbf{2 3 . 9 7 9}$ & $\mathbf{1 0 0}$ \\
\hline
\end{tabular}

Foram relacionadas 27 espécies de folhosas (Apêndice 1), dentre as quais predominam o Jatobá $(25,8 \%$ do volume total de folhosas ), o Ipê $(24,1 \%)$, o Pau-marfim $(7,1 \%)$ e a Cedroarana $(6,6 \%)$. Os fornecedores de 
folhosas estão concentrados na regiões Norte e Centro-Oeste, enquanto que a quase totalidade das coniferas é proveniente do próprio estado de São Paulo.

É importante destacar que apenas 3 indústrias estão secando madeira de uma única espécie do gênero Eucalyptus. Apesar da madeira de eucalipto ser considerada como a melhor alternativa na substituição de folhosas tropicais, e da recente divulgação de pesquisas relacionadas ao desdobro (Menezzi et al., 1999) e aos programas de secagem (Ciniglio, 1998; Vermaas, 1995); a indústria madeireira ainda mostra-se reticente quanto ao uso dessa matéria-prima.

\subsection{Características e práticas operacionais (questionário detalhado)}

Conforme anteriormente descrito (metodologia), foi solicitada autorização das indústrias para coleta de informações e material na linha de produção. Apenas $12 \%$ das indústrias autorizaram a continuidade da pesquisa, das quais foi possivel fazer uma avaliação mais detalhada.

As informações gerais dessas indústrias, abordando aspectos relativos a administração, espécies mais utilizadas e mercado de consumo, podem ser observados na Tabela 8. As características dos secadores e dos sistemas de controle constam das Tabelas 9 e 10, respectivamente. 
Tabela 8 - Informações gerais das indústrias amostradas (questionário detalhado).

\begin{tabular}{|c|c|c|c|c|}
\hline Indústrias & 1 & 2 & 3 & 4 \\
\hline $\begin{array}{l}\text { Quantidade de } \\
\text { secadores }\end{array}$ & 11 & 03 & 02 & 03 \\
\hline $\begin{array}{l}\text { Capacidade de } \\
\text { secagem }\left(\mathrm{m}^{3}\right)\end{array}$ & 750 & 172 & 130 & 300 \\
\hline $\begin{array}{c}\text { №. de } \\
\text { funcionários }\end{array}$ & 250 & 150 & 80 & 25 \\
\hline $\begin{array}{l}\text { Consumo } \\
\text { madeira/mês } \\
\left(\mathrm{m}^{3}\right)\end{array}$ & 2200 & 860 & 560 & 256 \\
\hline $\begin{array}{c}\text { Espécies mais } \\
\text { utilizadas }\end{array}$ & $\begin{array}{c}\text { Jatobá, Ipê, } \\
\text { Cumaru e Pau- } \\
\text { marfim }\end{array}$ & $\begin{array}{c}\text { Cedro, Louro, } \\
\text { Angelim e } \\
\text { Cedroarana }\end{array}$ & $\begin{array}{l}\text { Cedro, Louro e } \\
\text { Cedroarana }\end{array}$ & Pinus sp \\
\hline Produtos & Pisos e Forros & Portas e Janelas & Portas e Janelas & Embalagens \\
\hline $\begin{array}{l}\text { Mercado } \\
\text { consumidor }\end{array}$ & $\begin{array}{c}\text { Brasil, EUA, } \\
\text { Japão e Europa }\end{array}$ & $\begin{array}{c}\text { Brasil, Canadá, } \\
\text { Argentina e } \\
\text { Inglaterra }\end{array}$ & Brasil & Brasil \\
\hline
\end{tabular}

Um detalhe comum as indústrias 1,2 e 3 é o fato de consumirem apenas espécies tropicais (folhosas), a despeito da distância da fonte de matéria-prima. Quando inquiridas a esse respeito, a posição é similar; citando a execução de testes com madeira de reflorestamento (gênero Eucalyptus), mas alegando a falta de suprimento constante e a resistência do mercado consumidor como principais obstáculos a mudança de matéria-prima.

A indústria 4 consome somente madeira de reflorestamento, do gênero Pinus, matéria-prima com características e valor de mercado adequados ao produto final (embalagens). 
Tabela 9: Características dos secadores

\begin{tabular}{ccccc}
\hline Indústria & $\begin{array}{c}\text { Construção/Ano de } \\
\text { fabricacão }\end{array}$ & $\begin{array}{c}\text { Procedência/ } \\
\text { Marca }\end{array}$ & Carregamento & $\begin{array}{c}\text { Capacidade } \\
\text { útil }\left(\mathbf{m}^{3}\right)\end{array}$ \\
\hline $\mathrm{lA}\left({ }^{*}\right)$ & Aluminio/1995 & Itália/M & Vagonete & 65 \\
\hline $\mathrm{lB}\left({ }^{*}\right)$ & Alvenaria/1991 & Brasil/A & Empilhadeira & 60 \\
\hline 2 & Alvenaria-Aluminio/1992 & Brasil/C & Empilhadeira & 46 \\
\hline 3 & Alvenaria-Aluminio/1996 & Alemanha/L & Empilhadeira & 65 \\
\hline 4 & Alvenaria-Aluminio/1988 & Brasil/B & Empilhadeira & 100 \\
\hline
\end{tabular}

$\left({ }^{*}\right)$ A indústria 1 é a única que possue secadores de tipos diferentes, que serão designados por 1-A (carga por vagonete) e 1-B (carga por empilhadeira).

A participação no mercado externo mostra-se relacionada com o volume de produção. As indústrias que apresentam um consumo menor de madeira/mês ( 3 e 4), fornecem apenas para o mercado doméstico, enquanto que as que consomem mais ( 1 e 2), fornecem para um mercado mais diversificado, exportando também .

Este é um aspecto importante a ser destacado, pois, de acordo com o relato dos empresários, a aceitação do produto pelos consumidores externos forçou investimentos para aumentar a produção e, dessa forma, consolidar a marca e a posição no mercado. Talvez por esse motivo é que a indústria 4, por fabricar produtos de valor agregado menor e por possuir equipamentos mais antigos não tenha tido necessidade, ainda, de aperfeiçoar seus equipamentos. 
Tabela 10 - Características dos sistemas de controle da secagem.

\begin{tabular}{ccccc}
\hline Indústria & Programa de secagem & Fonte & Controle & Procedência \\
\hline 1 A & Umidade - Temperatura & Consultor $\left(^{*}\right)$ & Semi-automático & Itália \\
\hline 1 B & Umidade - Temperatura & Consultor $\left(^{*}\right)$ & Automático & EUA \\
\hline 2 & Umidade - Temperatura & Consultor $\left(^{*}\right)$ & Automático & Brasil \\
\hline 3 & Umidade - Temperatura & Consultor $\left(^{*}\right)$ & Automático & EUA \\
\hline 4 & Não utilizado & ---- & Manual & Brasil
\end{tabular}

$\left({ }^{*}\right)$ Os programas de secagem foram sugeridos pelos formecedores dos sistemas de controle.

Por outro lado, o tamanho da indústria não mostrou relação com os equipamentos usados na secagem. Nas Tabelas 9 e 10 pode ser verificado que a indústria 3 , que possui menor capacidade instalada de secagem, dispõe de secadores e sistema de controle importados (de tecnologia mais atualizada); enquanto que a indústria 2 dispõe exclusivamente de equipamentos nacionais e mesmo assim exporta. Possivelmente, a indústria 3 está almejando atingir novos mercados (externo).

A preocupação com a formação e a capacitação dos recursos humanos é comprovada na Tabela 11. As indústrias que agregam mais valor ao produto final e, por consequência, tem maior preocupação com qualidade, optaram pela política de formar, através de cursos específicos, a própria força de trabalho. 
Tabela 11 -Qualificação dos operadores de secador.

\begin{tabular}{ccccc}
\hline Indústria & Operador & Nível escolar & Experiência anterior & Aprendizado \\
\hline 1 & Funcionário & $\mathrm{I}^{\circ}$ grau & Nenhuma & Curso/prática \\
\hline 2 & Diretor & $3^{\circ}$ grau & Nenhuma & Curso/prática \\
\hline 3 & Funcionário & $1^{\circ}$ grau & Nenhuma & Curso/prática \\
\hline 4 & Funcionário & $1^{\circ}$ grau & Nenhuma & Prática \\
\hline
\end{tabular}

Foi observado que a indústria 4 não faz nenhum tipo de acompanhamento da secagem, e que em todas as outras indústrias o processo de secagem é acompanhando somente através dos controladores e os registros são armazenados apenas no equipamento de automação.

Existem no mercado vários fornecedores de equipamentos para o controle do processo que, além de fornecer assistência técnica, sugerem programas de secagem confiáveis; e as informações obtidas demostram a confiança da indústria em seus fornecedores. Contudo, seria recomendável o uso de fichas de acompanhamento, para contornar possiveis falhas de componentes eletrônicos e até para aferir seu funcionamento.

Observou-se que, conforme é recomendado, as indústrias preparam a carga com madeira da mesma espécie, espessura e com teores de umidade inicial dentro de uma mesma faixa. Entretanto, os resultados da Tabela 12 demonstram que, no empilhamento, não existe a mesma preocupação.

A situação da indústria 1-A é a melhor dentre todas, embora tenha sido constatadas variações no distanciamento entre os separadores na pilha ( $36 \mathrm{~cm}$ a $53 \mathrm{~cm}$ ), acima do desejável. Considerando que os resultados de 1-A e 1-B foram coletados na mesma indústria, o péssimo empilhamento constatado em 1-B pode ser atribuído a forma de carregamento do secador. 


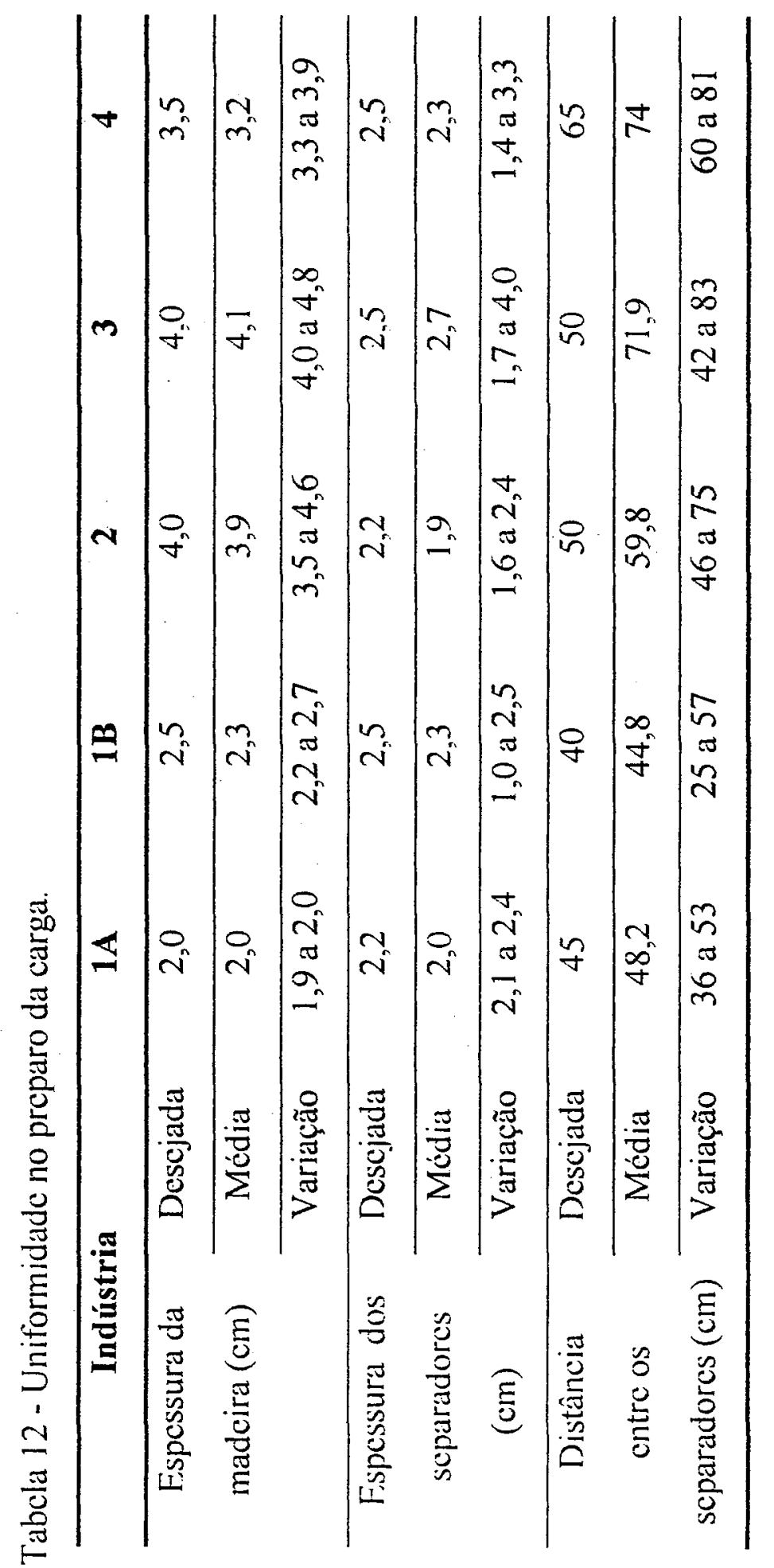


Os secadores nas indústrias 1-B, 2,3 e 4 são carregados por empilhadeira, isto é, a madeira é empilhada longe do secador e, posteriormente, transportada por empilhadeira até o interior da câmara de secagem. Essa movimentação contribui para que os separadores se movimentem e prejudiquem a qualidade do empilhamento. No secador carregado por vagonete (1-A) não ocorre a movimentação da pilha, uma vez que, na situação analisada, a madeira é empilhada diretamente sobre os vagonetes.

Como agravante das condições inadequadas de empilhamento devem ser citadas as variações na espessura da madeira (responsabilidade dos fornecedores da madeira serrada), espessura dos separadores e distânciamento entre os separadores (falta de cuidado nas indústrias). Uma melhor visão da variação da qualidade de empilhamento (formas correta e incorreta), é verificado através das Figuras 9 e 10.

O empilhamento mal feito é um fator que pode contribuir para aumentar a incidência de empenamentos durante a secagem, como observase na Tabela 13.

Tabela 13 - Quantificação dos defeitos de secagem.

\begin{tabular}{ccccccc}
\hline Indústrias & $\mathbf{1 ~ A}$ & $\mathbf{1 ~ B}$ & $\mathbf{2}$ & $\mathbf{3}$ & $\mathbf{4}$ \\
\hline \multicolumn{2}{c}{ Peças sem defeitos } & 66,6 & 55,0 & 50,0 & 54,0 & 40,3 \\
\hline \multirow{3}{*}{$\begin{array}{c}\text { Empenamentos } \\
\text { (\%) }\end{array}$} & Abaulamento & $\mathbf{1 , 0}$ & 2,0 & 0 & 0 & 0 \\
\cline { 3 - 7 } & Encurvamento & 26,9 & 32,0 & 38,0 & 38,0 & 36,0 \\
\cline { 3 - 7 } & Arqueamento & 2,5 & 4,0 & 9,0 & 9,0 & 18,0 \\
\cline { 3 - 7 } & Torcimento & 3,0 & 7,0 & 3,0 & 3,0 & 28,4 \\
\hline \multicolumn{2}{c}{ Colapso (\%) } & 0 & 0 & 0 & 0 & 0 \\
\hline
\end{tabular}




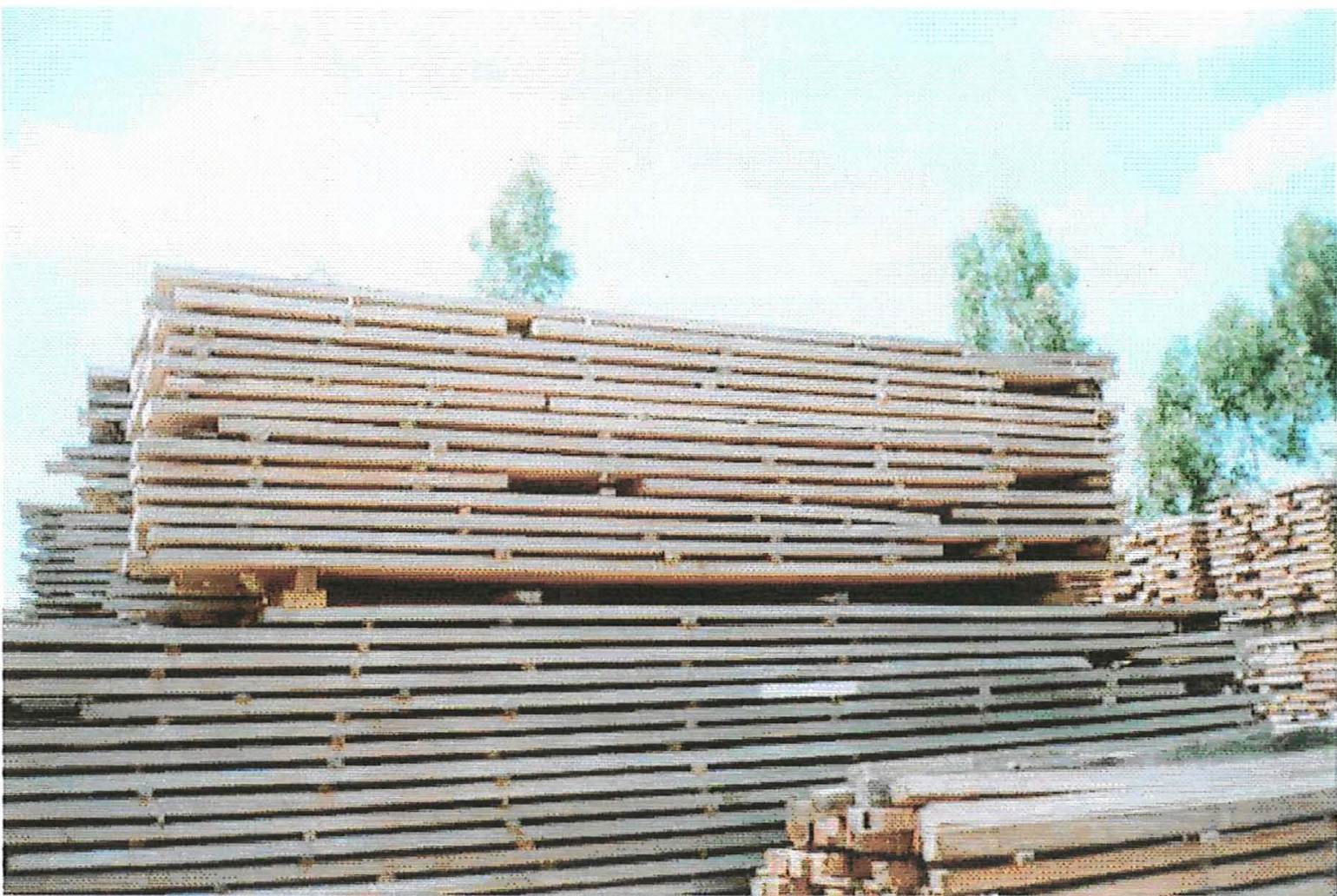

Figura 9 - Empilhamento realizado de forma incorreta.

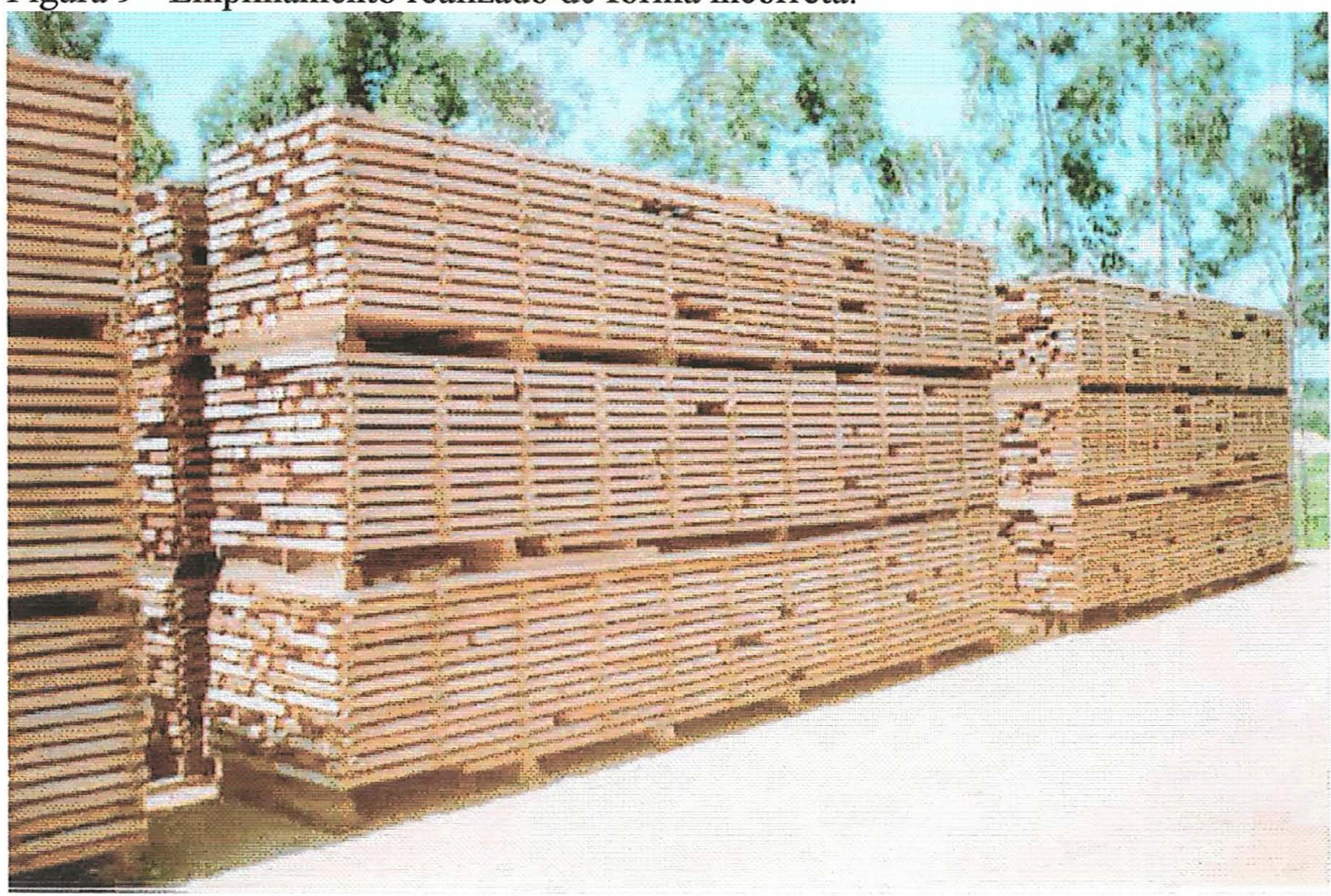

Figura 10 - Forma correta de empilhamento. 
O melhor empilhamento, observado na indústria 1-A, teve como resultado a secagem com o menor índice de peças empenadas. $\mathrm{O}$ defeito com maior incidência foi o encurvamento, cuja principal forma de prevenção é usar separadores com espessura uniforme e bem alinhados no sentido vertical da pilha (distância constante entre separadores).

A ausência do colapso, além de confirmar a importância da pré-secagem, é um indicativo que os programas de secagem adotados pelas indústrias são adequados. Por outro lado, a alta incidência de madeira com tensões residuais (Tabela 14) demonstra a falta de condicionamento no final do processo.

Tabela 14 - Incidência de tensões de secagem (em \% do total de amostras).

\begin{tabular}{ccccccc}
\hline \multicolumn{2}{c}{ Indústria } & $\mathbf{1 ~ A}$ & $\mathbf{1 ~ B}$ & $\mathbf{2}$ & $\mathbf{3}$ & $\mathbf{4}$ \\
\hline \multirow{4}{*}{ Tensões } & 1 (normal) & 40,4 & 0 & 0 & 23,1 & 16,7 \\
\cline { 2 - 7 } & 2 (moderada) & 44,7 & 0 & 19,4 & 15,4 & 35,7 \\
\cline { 2 - 7 } & 3 (forte) & 14,9 & 100 & 80,6 & 61,5 & 47,6 \\
\cline { 2 - 7 } & 4 (reversa) & 0 & 0 & 0 & 0 & 0 \\
\hline
\end{tabular}

Os resultados da distribuição de umidade dentro e entre peças (Tabela 15) comprovam que o final do processo poderia ser melhor conduzido. A madeira produzida pelas indústrias 2,3 e 4 apresentou uma amplitude de variação no teor de umidade final da ordem de $14,3 \%, 15,9 \%$ e $8,8 \%$ respectivamente; resultado característico de uniformização insuficiente ao final da secagem. 
Tabela 15 - Distribuição de umidade.

\begin{tabular}{ccccccc}
\hline \multicolumn{2}{c}{ Indústrias } & $\mathbf{1 ~ A}$ & $\mathbf{1 ~ B}$ & 2 & 3 & 4 \\
\hline \multirow{2}{*}{$\begin{array}{c}\text { Umidade } \\
\text { final (\%) }\end{array}$} & Desejada & 8,0 & 8,0 & 12,0 & 12,0 & 12,0 \\
\cline { 2 - 8 } & Média & 6,4 & 6,4 & 10,5 & 10,5 & 7,5 \\
\cline { 2 - 8 } & Variação & 4,9 a 10,2 & 5,7 a 8,6 & 6,1 a 20,4 & 8,4 a 24,3 & 5,1 a 13,9 \\
\hline Umidade & Média & 6,2 & 6,3 & 8,8 & 9,5 & 7,2 \\
\cline { 2 - 7 } externa (\%) & Variação & 5,5 a 8,1 & 5,4 a 8,1 & 6,2 a 12,2 & 8,0 a 14,9 & 4,8 a 12,6 \\
\hline Umidade & Média & 7,2 & 6,6 & 11,8 & 10,6 & 7,8 \\
\cline { 2 - 7 } interna (\%) & Variação & 5,6 a 11,3 & 5,4 a 10,2 & 6,2 a 28,5 & 8,6 a 29,4 & 5,3 a 18,5 \\
\hline
\end{tabular}

Pratt (1974), considera uma variação de $\pm 1 \%$ em torno da média como um excelente padrão de qualidade, em termos do teor de umidade final da madeira seca. Jankowsky (1999), afirma que, na prática, uma variação de $\pm 2 \%$ pode ser considerado um bom padrão de qualidade. $O$ resultado das indústrias 2 e 3 está muito acima das referências de literaturas.

Para diminuir a amplitude de variação da umidade final e presença de tensões, o tempo do processo deve ser maior, principalmente nas fases de uniformização e condicionamento, respectivamente.

Considerando que a indústria 4 não segue um programa de secagem, controla o secador manualmente e produz embalagem (produto de pequeno valor agregado), era esperado que a madeira seca tivesse padrão de qualidade compatível (baixo).

A análise dos resultados gerais mostra que na indústria 10 secador A está produzindo madeira com padrão de qualidade superior ao secador $\mathrm{B}$ e, na média, superior ao das indústrias 2,3 e 4 . A partir desta constatação é possivel comentar os aspectos relacionados ao tipo de secador e a inexistência de procedimentos, mesmo que simples, voltados ao controle de qualidade. 
Um secador de vagonetes (A) caracteriza-se por ser um secador longo e estreito, enquanto que uma característica construtiva do secador de carga por empilhadeira (B) é ser largo e profundo.

Durante a secagem, a distância a ser percorrida pela corrente de ar ao atravessar a pilha é menor no secador do tipo (A) do que no tipo (B). O resultado, ao longo do processo, é uma secagem mais homogênea no secador de vagonetes.

Quando, no caso do secador carregado por empilhadeira, existe o agravante da movimentação das pilhas para o carregamento, é de se esperar uma secagem mais demorada e com tendência a um padrão de qualidade inferior. Esta situação é bastante clara na indústria 1, onde o tipo de madeira e os procedimentos operacionais são similares para os dois tipos de secador, e o padrão de qualidade da madeira seca no secador (A) é superior.

As indústrias 2, 3 e 4, além de disporem de secadores do tipo (B), trabalham com madeira mais grossa (maior espessura), o que implica na necessidade de uma secagem mais cuidadosa. Como não existem procedimentos para controle de qualidade, o produto final tem padrão de qualidade abaixo do que seria desejável.

No caso da indústria 4 , que trabalha com madeira de secagem rápida (Pinus sp), seria mais recomendável o secador de vagonetes; mas, analisando a tabela 8 , é possível constatar que essa indústria está com capacidade de secagem ociosa. 
Nenhuma das indústrias pesquisadas adota ou executa avaliações de qualidade da madeira seca, quantificação de defeitos ou registros das operações. São procedimentos simples que podem ser executados pelos operadores, e a avaliação contínua dos resultados permite identificar a necessidade de mudanças nos procedimentos operacionais; de forma a melhorar o padrão de qualidade do produto e a produtividade da indústria. 


\section{CONCLUSÕES}

A análise das informações coletadas junto as indústrias, permite as seguintes conclusões, restritas ao estado de São Paulo:

1) a secagem convencional é praticada por um reduzido número de indústrias. Estima-se que esse grupo represente menos de $1 \%$ do setor madeira/mobiliário;

2) o padrão de secador mais comum é o de fabricação nacional, construído em alvenaria, com ventilação superior e capacidade de secagem inferior a $60 \mathrm{~m}^{3}$;

3) a qualificação da força de trabalho ainda deve ser considerado como prioridade para melhorar os padrões de qualidade e produtividade da indústria madeireira;

4) nas indústrias que buscam agregar valor ao produto final existe o reconhecimento sobre a importância da secagem no processo produtivo, que se reflete na aquisição de equipamentos com tecnologia atualizada e na qualificação da força de trabalho;

5) o padrão de qualidade da madeira seca pode ser melhorado, pois ainda está abaixo das referências de literatura; 
6) para as condições da pesquisa, o melhor padrão de qualidade foi observado no secador carregado por vagonetes. Isto significa, também, que o controle de processo deveria ser mais rigoroso nos secadores carregados por empilhadeira;

7) a principal prática operacional que deve ser aprimorada é o empilhamento, principalmente quanto a separadores com espessura uniforme e distanciamento constante entre eles na pilha;

8) os programas de secagem usados nas indústrias avaliadas são adequados, mas ainda deficientes nas fases de uniformização e condicionamento;

9) atingir um padrão de qualidade superior, e a sua posterior manutenção, depende da execução de procedimentos voltados ao controle de qualidade, principalmente quanto a quantificação de defeitos, da distribuição de umidade e das tensões residuais. 
ANEXO A : Questionário simplificado 


\section{PESQUISA \\ UNIVERSIDADE DE SÃO PAULO/ESALQ/LCF \\ CURSO DE PÓS GRADUACÃO EM CIÊNCIA E TECNOLOGIA DE MADEIRAS}

\section{EMPRESA:}

No de funcionários: Atividade (Produtos) :

Consumo médio mensal (m3):

Espécies utilizadas/quantidade $\overline{\left(\mathrm{m}^{3} / \mathrm{mês}\right)}$ :

Esp. em secagem $\left(\mathrm{m}^{3} / \mathrm{mês}\right)$ :

Mercado consumidor :

Perdas do processo (aproveitamento \%):

SECADOR(ES):Marca: Ano: Quantidade: $\mathrm{m}^{3}$ :

Carregamento: Vagoneta ( ) Empilhadeira ( ) Construção: Alvenaria ( ) Alumínio ( ) Alvenaria/Alumínio ( ) Conhece outras empresas que tenham secadores (Quais?):

CONTROLADOR(ES): Automático ( ) Semi Automático ( ) Manual ( ) Marca: Pontos de medição de umidade:

OUTROS EQUIPAMENTOS: Termômetros: Medidores elétricos de umidade (marca):

USO DE PROGRAMAS DE SECAGEM: Sim ( ) Não ( ) Qual:

PESSOAL DE OPERAÇÃO: Proprietário ( ) Funcionário ( )

- Nivel escolar -

- Aprendizado sobre a técnica -

- Experiência anterior -

- Problemas encontrados pela Empresa ( falta de assistência técnica, interesses em cursos e assistência para operadores, etc. ).

\section{ASSISTÊNCIA TÉCNICA DO SECADOR :}

Particular ( ) Qual? Nota $(0-5)$ : ou Fornecedor do secador ( )

Obs: Anexar, se possível, um cartão da Empresa e cópia de uma ficha de secagem. 
ANEXO B : Questionário detalhado 


\section{PESQUISA \\ UNIVERSIDADE DE SÃO PAULO/ESALQ/LCF \\ CURSO DE PÓS GRADUAÇÃO EM CIÊNCIA E TECNOLOGIA DE MADEIRAS}

\section{1) ASPECTOS GERAIS}

Empresa:

Endereço:

Número de operários :

Atividade (produtos):

Mercado consumidor (países):

\section{2) MATÉRIA-PRIMA}

\begin{tabular}{|l|l|l|l|}
\hline Espécies (nomes vulgares) & Consumo médio mensal $\left(\mathrm{m}^{3}\right)$ & $\%$ & Região (fonte) \\
\hline & & & \\
\hline & & & \\
\hline & & & \\
\hline & & & \\
\hline & & & \\
\hline & & & \\
\hline & & & \\
\hline & & & \\
\hline & & & \\
\hline
\end{tabular}




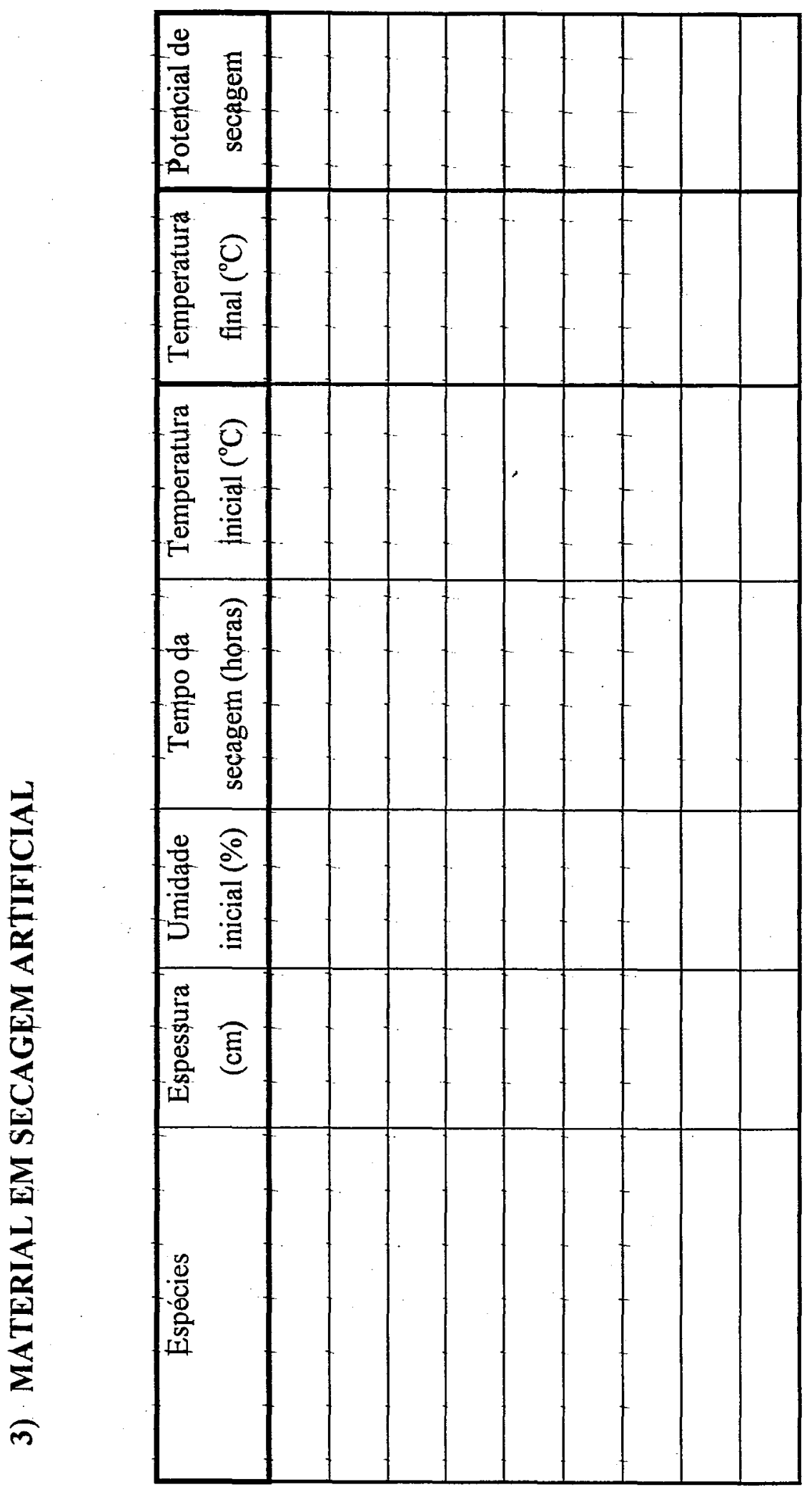


4) SECADORES

\begin{tabular}{|l|l|l|l|}
\hline \multicolumn{1}{|c|}{ Tipos } & \multicolumn{1}{|c|}{ 1 } & & 2 \\
\hline Marca & & & \\
\hline Modelo & & & \\
\hline Nacionalidade & & & \\
\hline Quantidade de câmaras & & & \\
\hline Ano de fabricação & & & \\
\hline Capacidade (m ${ }^{3}$ ) & & & \\
\hline Material de construção & & & \\
\hline Dimensões (L x C x H) & & & \\
\hline Quantidade de ventiladores & & & \\
\hline Posição dos ventiladores & & & \\
\hline Reversível (sim ou não) & & & \\
\hline Sistema de carregamento & & & \\
\hline Sistema de aquecimento & & & \\
\hline Sistema de umidificação & & & \\
\hline Outras informações & & & \\
\hline
\end{tabular}




\section{5) CONTROLE DA SECAGEM}

\subsection{Equipamento}

\begin{tabular}{|l|l|l|l|}
\hline \multicolumn{1}{|c|}{ Tipos } & 1 & 2 & 3 \\
\hline Marca & & & \\
\hline Modelo & & & \\
\hline Nạcionalidade & & & \\
\hline Ano de instalação & & & \\
\hline $\begin{array}{l}\text { Princípio de funcịonamento (manual, } \\
\text { semi-automático ou automático) }\end{array}$ & & & \\
\hline Pontos de umidade por câmara & & & \\
\hline Distribuição dos pontos de umidade & & & \\
\hline Outras informações & & & \\
& & & \\
\hline
\end{tabular}

\subsection{Presença de equipamentos complementares}
a) Termômetros :
b) Estufas para corpos de prova:
c) Balança de previsão:
d) Medidores elétricos de umidade da madeira:
e) Outros : 


\subsection{Acompanhamento da secagem}

a) Presença de ficha de acompanhamento (por pesagem):

b) Intervalos de controle da secagem (dias):

c) Programa de secagem - controle (Ex.: umidade/temperatura):

d) Fonte do programa de secagem :

e) Testes de qualidade (distribuição de umidade e tensões):

f) Outras informações :

\section{6) RECURSOS HUMANOS}

a) Proprietário ( ) Funcionário ( )

b) Nivel escolar :

c) Aprendizado sobre a técnica :

d) Experiência anterior :

e) Nível de Responsabilidade ( se o operador ou a produção que decide o final da secagem):

f) Sugestões de melhoria $=$

g) Problemas encontrados pela Empresa ( falta de assistência técnica, interesses em cursos e assistência para operadores, etc. ). 


\section{7) ASSISTÊNCIA TÉCNICA}

\subsection{Secadores}
a) $\operatorname{Marca}(\mathrm{A})$ :
b) Particular ( ) Fornecedor ( )
c) Nota $(0-5)$ :
a) Marca (B):
b) Particular ( ) Fornecedor ( )
c) Nota $(0-5)$ :
a) Marca (C):
b) Particular ( ) Fornecedor ( )
c) Nota $(0-5)$ :

\subsection{Controladores}
a) Marca (A):
b) Particular ( ) Fornecedor ( )
c) Nota $(0-5)$ :
a) Marca (B):
b) Particular ( ) Fornecedor ( )
c) Nota $(0-5)$ : 


\section{8) QUANTIFICAÇÃO DE DEFEITOS}

a) Medições ( $15 \%$ das peças da carga)

\begin{tabular}{|c|c|c|}
\hline Tipos de defeitos & Quantidade de peças com defeitos & Total \\
\hline Abaulamento & & \\
\hline Encurvamento & & \\
\hline Arqueamento & & \\
\hline Torcimento & & \\
\hline Colapso & & \\
\hline
\end{tabular}

\section{9) UNIFORMIDADE NO PREPARO DA CARGA}

a) Espécie da matéria-prima:

b) Espessura desejada da madeira:

c) Espessura desejada dos separadores (tabiques):

d) Distância desejada entre os separadores : 
e) Medições (em todas as pilhas que compõe a carga)

\begin{tabular}{|l|l|l|l|l|l|l|l|l|l|l|l|l|l|l|}
\hline \multicolumn{2}{|c|}{ Espessura da madeira } & \multicolumn{6}{|c|}{ Espessura dos separadores } & \multicolumn{5}{c|}{ Distância entre os } \\
\hline & & & & & & & & & \\
\hline
\end{tabular}




\section{REFERÊNCIAS BIBLIOGRÁFICAS}

BAKER, W.J. How wood dries. Madison: Forest Products Laboratory, 1956. 9p. (Report, 1642).

BOONE, R.S.; KOZLIK, C.J.; BOIS, P.J.; WENGERT, E.M. Dry kiln schedules for commercial woods: temperate and tropical. Madison: USDA, Forest Service, Forest Products Laboratory, 1995. 158p.

BRANDÃO, A.T.O. Determinação de metodologia para a indicação de programas de secagem de madeiras. Piracicaba, 1989. 100p. Dissertação (M.S.) - ESALQ/USP.

BRASIL. Instituto Brasileiro de Desenvolvimento Florestal. Madeiras da Amazônia: características e utilização - Floresta Nacional do Tapajós. Brasília: IBDF, 1981. V.1, 113p.

BRASIL. Instituto Brasileiro de Desenvolvimento Florestal. Madeiras da Amazônia: características e utilização - Estação experimental de Curuá-una. Brasília: IBDF, 1988. V. 2, 236p.

BROWN, H.P.; PANSHIN, A.J.; FORSAITH, C.C. Textbook of wood technology. New York: McGraw-Hill, 1949. 652p.

BURGER, L.M.; RICHTER, H.G. Anatomia da madeira. São Paulo: Nobel, 1991. 154p. 
CAMPANARIO, M. A. \& SILVEIRA, C. E. F. Programa de atualização tecnológica industrial (PATI). São Paulo. IPT/ Divisão de economia e engenharia de sistemas. $1988.105 \mathrm{p}$.

CAMPBELL, G.S.; HARTLEY, J. Drying and dried wood. In: HILLIS, W. E. ; BROWN, A.G. Eucalypts for wood production. Austrália: Academic Press, 1988. 328-336 p.

CARLOS, V. J. Secagem da madeira ao ar. São Paulo, Boletim ABPM nº 17. 1984. 23p.

CARSON, G. B. (ed) - Production Handbook. Ronald Press Company, New York, 1958. (segunda edição, paginação diversa).

CINIGLIO, G. Avaliação da secagem de madeira serrada de Eucalyptus grandis e Eucalyptus urophylla. Piracicaba, 1998. 69p. Dissertação (Mestrado) Escola Superior de Agricultura "Luiz de Queiroz", Universidade de São Paulo.

COMPANHIA DE DESENVOLVIMENTO ECONÔMICO DO PARANÁ (CODEPAR). O Paraná e a economia madeireira. Curitiba, $1964.2 \mathrm{v}$. CONFEDERAÇÃO NACIONAL DA INDÚSTRIA. A atuação da Confederação

Nacional da Indústria junto à Micro, Pequena e Média Indústria. Rio de Janeiro/RJ. 1987. 32p.

CONSELHO FEDERAL DE ENGENHARIA, ARQUTTETURA E AGRONOMIA (CONFEA) - Leis, Decretos e Resoluções. (Resolução ${ }^{\circ}$. 218, de 29/06/73). Brasília, CONFEA, 1987. pg. B-32 a B-37.

CUNHA, J.L.F. \& BARTHOLO, M. B. O sistema de garantia de qualidade e sua importância. In: CONGRESSO BRASILEIRO DE CONTROLE DE QUALIDADE 1. São Paulo, 1986. Anais. São Paulo. p.15-21.

ESAU, K. Anatomia das plantas com sementes. São Paulo. Edgard Blucher. 1974. 93p. 
FRANZOI, L. C. N. A secagem da madeira. CETEMO-NIT/MM. SENAI. Bento Gonçalves/RS. 1992. 39 p.

GALVÃO, A.P.M. Secagem acelerada: Programa para a madeira de Jatobá (Hymenea stilbocarpa Hayne). IPEF, $\mathrm{n}^{\circ}$.12. Jun. 1976. 151-161 p.

GALVÃO, A.P.M.; JANKOWSKY, I. P. Secagem racional da madeira. São Paulo: Nobel, 1985. 111p.

GOMIDE, J. L. Secagem de madeira. UFV. Viçosa/MG, 1973. 76p.

HART, C.A. The drying of wood. Raleigh: North Caroline Agricultural Extension Service, 1965. 24p. (Extension Circular, 471).

HENRIQUEZ, E. Z. Comparação dos métodos de secagem para madeira de Pimus caribaea var. hondurensis.. Piracicaba, 1986. 78p. Dissertação ( M. S.). ESALQ/USP.

HILDEBRAND, R. Kiln drying of sawn timber. Berlin: Maschinenbau GmbH, 1970. 198p.

IBGE. Anuário Estatístico Brasileiro. Brasília, 1994.

IBGE. Anuário Estatístico Brasileiro. Brasília, 1996.

INSTITUTO DE PESQUISAS TECNOLÓGICAS. Divisão de Madeiras.

Madeira: o que é e como pode ser processada e utilizada. São Paulo:

Boletim Técnico ABPM 36. 1985. 189p.

JANKOWSKY, I. P. Drying tropical wood for quality products. IUFRO WORLD CONGRESS, Division 5 Proceedings, 1988 . 1-7p.

JANKOWSKY, I. P. Ensino da Preservação de Madeiras nos cursos de

Engenharia Florestal do Brasil. In: III ENCONTRO BRASILEIRO EM PRESERVAÇÃo DE MADEIRAS. São Paulo, 1989. Anais. São Paulo. 253-260 p.

JANKOWSKY ,I. P. Fundamentos do controle de qualidade. Revista Industria Moveleira. Número 25. Caxias do Sul, 1991. 40-41p 
JANKOWSKY, I P. Equipamentos e processos para secagem de madeiras. In: SEMINÁRIO INTERNACIONAL DE UTILIZAÇÃO DE MADEIRA DE EUCALIPTO PARA SERRARIA. São Paulo, 1995. IPEF/IPT/IUFRO/ESALQ/USP. 1995. Anais.. 109-118 p.

JANKOWSKY, I. P. ; BILIA, F. A. C.; DUCATTI, M. A. Ensaio rápido para a seleção de programas de secagem. Relatório técnico CNPq 510555/93-4. Mar. Piracicaba. 1997. 12p.

JANKOWSKY, I. P. - Desenvolvimento e pesquisa em secagem de madeiras. WORKSHOP SOBRE SECAGEM DA MADEIRA DE REFLORESTAMENTO. Piracicaba, IPEF/ESALQ/USP. 1998

JANKOWSKY, I. P. Melhorando a eficiência dos secadores para madeira serrada.

In: IV CONGRESSO INTERNACIONAL DE COMPENSADO E MADEIRA TROPICAL - Belém, 1999. Anais. Pará. 70p.

KOLLMANN, F.F.P.; CÔTÉ, W.A. Principles of wood science and technology. Berlin: Springer-Verlag, 1968. 592p.

LAMB, F. M. Targenting and achieving the final moisture content . In:

Profitable Solutions for Quality Drying of Softwoodes and Hardwoods. Charlote, 1994. 54-56 p.

LAUSCH, M. A experiência internacional na produção de secadores. WORKSHOP SOBRE SECAGEM DA MADEIRA DE REFLORESTAMENTO. Piracicaba, IPEF/ESALQ/USP. 1998

LIVINGSTONE, J. M. Pesquisa de mercado: Uma abordagem operacional. São Paulo. Atlas, 1989. 126 p.

MAINIERI, C.; CHIMELO, J.P. Fichas de características das madeiras brasileiras. São Paulo: IPT;DIMAD, 1989. 418p. 
MARQUESINI, A. G. Estudo do processo de implantação de sistemas da qualidade normatizados no setor industrial brasileiro. São Paulo / 1995. Dissertação (M.S.)- EP/USP. 111p .

MARTINS, V. A. Secagem de madeira serrada. Brasília: Ministério da agricultura IBDF/LPF, 1988. 89p.

MARTINS, V.A.; MARQUES, M.H.B.; MENDES, A.S. Madeiras da Amazônia de secagem rápida. Madeira \& Tecnologia, $\mathrm{n}^{\circ} .7$. Nov/Dez. 1997. 44-50 p.

MCFARLANE, K. A. \& CASTRO A. A. Gerenciamento da qualidade com participação integrada. In: $6^{\mathrm{o}}$ CONGRESSO BRASILEIRO DE CONTROLE DE QUALIDADE. São Paulo, 1990. ABTCP. Anais. São Paulo. 130 p.

McMILLEN, J.M. Accelerated kiln drying of presurfaced 1-inch Northern Red Oak. Madison: USDA, Forest Service. 1969. 29p. (Research Paper - FPL, 122).

MENEZZI, C. H. S.; NAHUZ, M. A. R. ; SOUZA, M. R. Uma proposta para o processamento da madeira de eucalipto. Revista silvicultura, $\mathrm{n}^{\mathrm{o}} 80$. Out/Nov/Dez. 99. 30-32 p.

MOLL, R. F. Gerenciamento em ambiente de qualidade total. In: 5o CONGRESSO BRASILEIRO DE CONTROLE DE QUALIDADE. São Paulo, 1990. ABTCP. Anais. São Paulo. 200p.

NAHUZ, M. A. R. O estado da arte na pesquisa tecnológica em madeiras. In: I ENCONTRO BRASILEIRO DE ECONOMIA FLORESTAL, Curitiba, 1988. IPT/SP. Anais. Paraná. 10 p.

NORTHWAY, R.L. Drying strategies for plantation-grown Eucalypts. In: 5th INTERNATIONAL IUFRO WOOD DRYING CONFERENCE. Quebec, 1996. Canadá. 289-296 p . 
OLIVEIRA, L. C. S. Perguntas e respostas em secagem de madeiras. São Paulo, IPT. 1981. 36p.

OLIVEIRA, J. T. S. A relação água-madeira em Eucalipto: o grande desafio. WORKSHOP SOBRE SECAGEM DA MADEIRA DE REFLORESTAMENTO. Piracicaba, IPEF/ESALQ/USP. 1998.

PERELYGIN, L. M. Science of wood. Moscow: Higher School Publishing House, 1965. 200p.

PONCE, R. M.; WATAI, L. T. Manual de secagem de madeira. Brasília, MIC/STI/IPT. 1985. 70p.

PONCE, R. M. Madeira serrada de eucalipto: Desafios e perspectivas. In: SEMINÁRIO INTERNACIONAL DE UTLLIZAÇÃO DA MADERIA DE EUCALIPTO PARA SERRARIA. São Paulo. IPEF/IPT/IUFRO/ESALQ/USP. 1995. Anais. 132p.

PRATT, G.H. Timber drying manual. London: Department of the Environment/Building Research Establishment, 1974. 152p.

RASMUSSEN, E. F. Dry Kiln: operato's manual. Madison: Forest Products Laboratory, 1961, 197p.

MARCENARIAS UTILIZAM EQUIPAMENTOS ANTIGOS. Revista da madeira. Curitiba/PR. Edição nº. 24 - Ano IV. Set/Out. 1995. P 35.

MERCADO E COMERCIALIZAÇÃO DE MADEIRAS. Revista da madeira.

Curitiba/PR. Edição. nº. 46 - Ano VIII. Jan/Fev. 2000 . 22-24 p.

SIAU, J.F. Flow in wood. New York: Syracuse University Press, 1971. 131p.

SIAU, J.F. Transport processes in wood. Berlin: Springer-Verlag, 1984. 245p.

SKAAR, C. Wood-water relations. Berlin: Springer-Verlag, 1988. 263p.

STCP-ENGENHARIA DE PROJETOS Ltda. Secagem de madeiras serradas.

Curitiba: 1990. 68p. 
TAGLiaCARnE, G. Pesquisa de mercado: técnica e prática. $2^{\underline{a}}$ ed. São Paulo. Atlas, 1989. 469 p.

TOMASELLI, I. Condições da secagem artificial de madeiras serradas no Paraná e Santa Catarina. Curitiba, 1974. 111p. Dissertação (M.S.) - UFPr.

TOMASELLI, I. Secagem a alta temperatura: um processo aplicável às condições brasileiras. Brasil Madeira. Curitiba, 3(27): 32-35, 1979.

TOMASELLI, I. Secagem de madeira. Curitiba: FUPEF, 1980. 29p.

TOMASELLI, I. Pesquisa e desenvolvimento em secagem de madeiras. WORKSHOP SOBRE SECAGEM DA MADEIRA DE REFLORESTAMENTO. Piracicaba, IPEF/ESALQ/USP. 1998.

TRINDADE, C. Desenvolvimento de um sistema de controle de qualidade para a atividade florestal. - Viçosa, 1993. 164p. Dissertação ( M.S.). UFV.

VERMAAS, H.F. Drying Eucalipts for quality: Material characteristics, predrying treatments, drying methods, schedules and optimization of drying quality. In: SEMINÁRIO INTERNACIONAL DE UTILIZAÇÃO DE MADEIRA DE EUCALIPTO PARA SERRARIA. São Paulo. IPEF/IPT/IUFRO/ESALQ/USP. 1995. Anais. 132 p.

VIANA, L. O. Experiências do SENAI/CETMAM com secagem de Eucalipto. In: IV SEMADER - SEMINÁRIO SOBRE PROCESSAMENTO E UTILIZAÇÃO DE MADEIRAS DE REFLORESTAMENTO. Curitiba, 1996. Anais. $119-130 \mathrm{p}$.

WENGERT, G.; DENIG, J. Lumber drying: today and tomorrow. Forest Products Journal, v.45, n.5, p. 23-30, May. 1995.

ZENID, G. J. Controle de qualidade de madeira serrada de coníferas destinada a exportação. In: $X$ ENCONTRO NACIONAL DOS REFLORESTADORES. Atibaia. IPT/SP. 1989. Anais. 5 p. 


\section{APÊNDICE 1}

Espécies utilizadas. 
Espécies utilizadas

\begin{tabular}{|c|c|c|c|c|c|c|}
\hline Espécies (nome vulgar) & $\begin{array}{l}\mathbf{A} \\
\mathbf{B} \\
\end{array}$ & Região de origem & $\begin{array}{c}\begin{array}{c}\text { № de } \\
\text { indústrias }\end{array} \\
\end{array}$ & $\begin{array}{c}\text { Volume } \\
\text { total }\left(\mathrm{m}^{3}\right)\end{array}$ & $\% \mathrm{C}$ & $\% \mathrm{D}$ \\
\hline Álamo & $\bar{A}$ & Argentina & 1 & 170 & 0,9 & 0,7 \\
\hline Andiroba & B & PA & 1 & 35 & 0,7 & 0,1 \\
\hline Angelim & B & MS & 2 & 260 & 5,3 & 1,1 \\
\hline Angelim Pedra & B & PA/MT & 2 & 100 & 2,1 & 0,4 \\
\hline Cabreúva Vermelha & B & MA/PA/MT & 3 & 120 & 2,5 & 0,5 \\
\hline Caixeta & $\mathrm{B}$ & RO & 2 & 200 & 4,1 & 0,8 \\
\hline Cedro & $\mathrm{B}$ & AC/RO/PA & 5 & 308 & 6,3 & 1,3 \\
\hline Cedroarana & $\mathrm{B}$ & MS/PA/MT & 3 & 320 & 6,6 & 1,3 \\
\hline Cerejeira & $\mathrm{B}$ & MS/PA/MT & 1 & 20 & 0,4 & 0,1 \\
\hline Cumaru & $B$ & MS/MT & 1 & 224 & 4,6 & 0,9 \\
\hline Eucalipto & $\mathrm{A}$ & SP & 2 & 70 & 0,4 & 0,3 \\
\hline Freijó & B & Não informado & 1 & 20 & 0,4 & 0,1 \\
\hline Gmelina & A & Não informado & 1 & 190 & 1,0 & 0,8 \\
\hline Imbuia & B & Não informado & 1 & 100 & 2,1 & 0,4 \\
\hline Ipề & B & RO/AC/MT/MA & 5 & 1173 & 24,1 & 4,9 \\
\hline Jatobá & B & $\mathrm{RO} / \mathrm{AC} / \mathrm{MT} / \mathrm{MA}$ & 7 & 1255 & 25,8 & 5,2 \\
\hline Louro Tamaquaré & $\mathrm{B}$ & PA & 1 & 20 & 0,4 & 0,1 \\
\hline Louro Vermelho & B & PA & 2 & 30 & 0,6 & 0,1 \\
\hline Mogno & B & Não informado & 4 & 75 & 1,5 & 0,3 \\
\hline Muiracatiara & B & PA & 2 & 40 & 0,8 & 0,2 \\
\hline Pau-marfim & B & Paraguai & 3 & 345 & 7,1 & 1,4 \\
\hline Peroba & $\mathrm{B}$ & Não informado & 1 & 13 & 0,3 & 0,1 \\
\hline Pinus sp & $\mathrm{A}$ & SP/PR/MG & 19 & 18.685 & 97,8 & 77,9 \\
\hline Quaruba & B & PA & 1 & 20 & 0,4 & 0,1 \\
\hline $\begin{array}{l}\text { Outros (Goiabão, Tauari, } \\
\text { Roxinho, Perobinha, Jatobá- } \\
\text { mirim, Sucupira e Tamarino }\end{array}$ & B & $\begin{array}{l}\text { PA/MA/MS/ } \\
\text { MT/RO/AC }\end{array}$ & 7 & 186 & 3,8 & 0,8 \\
\hline $\begin{array}{c}\text { Total Coniferas } \\
\text { (reflorestamento) }\end{array}$ & 3 & & 22 & 19.045 & 99,6 & 79,4 \\
\hline $\begin{array}{c}\begin{array}{c}\text { Total Eucalipto } \\
\text { (reflorestamento) }\end{array} \\
\end{array}$ & 1 & & 2 & 70 & 0,4 & 0,3 \\
\hline Total nativas & 27 & & 27 & 4864 & 100 & 20,3 \\
\hline TOTAL & 31 & & 43 & 19979 & 100 & 100 \\
\hline
\end{tabular}

Onde:

$\mathrm{A}=$ Madeira de reflorestamento.

$\mathrm{B}=$ Madeira de nativas.

$\% \mathrm{C}=$ Porcentagem do volume em relação a origem (reflorestamento ou nativas).

$\% \mathrm{D}=$ Porcentagem do volume total (reflorestamento e nativas).

Obs.: 1) Várias indústrias trabalham tanto com espécies de reflorestamento como nativas. 